IZA DP No. 9358

Entering and Leaving Self-Employment: A Panel Data Analysis for 12 Developing Countries

Yoonyoung Cho

David Robalino

Jose Manuel Romero

September 2015 


\title{
Entering and Leaving Self-Employment: A Panel Data Analysis for 12 Developing Countries
}

\author{
Yoonyoung Cho \\ World Bank and IZA \\ David Robalino \\ World Bank and IZA \\ Jose Manuel Romero \\ World Bank \\ Discussion Paper No. 9358
September 2015
}

IZA

P.O. Box 7240

53072 Bonn

Germany

Phone: +49-228-3894-0

Fax: +49-228-3894-180

E-mail: iza@iza.org

Any opinions expressed here are those of the author(s) and not those of IZA. Research published in this series may include views on policy, but the institute itself takes no institutional policy positions. The IZA research network is committed to the IZA Guiding Principles of Research Integrity.

The Institute for the Study of Labor (IZA) in Bonn is a local and virtual international research center and a place of communication between science, politics and business. IZA is an independent nonprofit organization supported by Deutsche Post Foundation. The center is associated with the University of Bonn and offers a stimulating research environment through its international network, workshops and conferences, data service, project support, research visits and doctoral program. IZA engages in (i) original and internationally competitive research in all fields of labor economics, (ii) development of policy concepts, and (iii) dissemination of research results and concepts to the interested public.

IZA Discussion Papers often represent preliminary work and are circulated to encourage discussion. Citation of such a paper should account for its provisional character. A revised version may be available directly from the author. 
IZA Discussion Paper No. 9358

September 2015

\section{ABSTRACT \\ Entering and Leaving Self-Employment: A Panel Data Analysis for 12 Developing Countries*}

This paper examines the determinants of labor market transitions into and out of selfemployment (own-account work and employer), using panel data from 12 developing countries in multiple regions. Despite cross-country heterogeneity, a few consistent patterns emerge. Entering the labor market through, or moving from wage employment into, ownaccount work is generally infrequent even during economic downturns, suggesting that ownaccount work is not an automatic choice for subsistence. Some better educated and older workers become employers by starting their business with paid employees or by growing their business from own-account work, although the overall chances of becoming employers are quite low and employer downsizing to own-account work is common. Reflecting the frequent transitions between own-account work and employer statuses, in many cases, particularly in middle-income countries, a substantial proportion of own-account workers share common characteristics with employers (and vice versa). The results suggest that there is a role for programs to support employers sustain its activities and facilitate ownaccount workers to become employers.

JEL Classification: $\quad 012, \mathrm{~J} 24$

Keywords: labor market transitions, self-employment, entrepreneurship

Corresponding author:

Yoonyoung Cho

World Bank

1818 H Street NW

Washington, DC 20433

USA

E-mail: ycho1@worldbank.org

\footnotetext{
* This paper has been prepared as part of a broader entrepreneurship project at the Social Protection and Labor Unit of the World Bank. The study was funded by the governments of Austria, Germany, Norway, South Korea, and Switzerland under the auspices of the Multi-Donor Trust Fund on Labor Markets, Job Creation, and Economic Growth. The findings, interpretations, and conclusions expressed here are those of the authors and should not be attributed to the World Bank, its management, its Executive Board of Directors, or any of its member countries.
} 


\section{Introduction}

More than half of the world's workers are engaged in some form of self-employment, whether they be employers or own-account workers; many are engaged in agriculture or small household enterprises without pay. Several studies have tried to understand the nature of self-employment by examining the key characteristics of these workers (de Mel, McKenzie, and Woodruff 2008; Djankov and others 2005, 2006; Gindling and Newhouse 2014), the reasons and motivations behind self-employment (Bosch and Maloney 2010; Fields 1975, 2005; Maloney 1999; Perry and others 2007), which selfemployed workers are able to succeed (de Mel, McKenzie, and Woodruff 2008; Mondragón-Vélez and Peña 2010), and which self-employed workers could potentially succeed but fail to do so (Gindling and Newhouse 2014; Grimm, Knorringa, and Lay 2012).

An important barrier to this research has been a lack of panel data to analyze transitions into and out of self-employment over time. A few studies focus on Latin American countries (for example, Bosch and Maloney 2010; Maloney 1999; Mondragón-Vélez and Peña 2010); a few others have constructed longitudinal surveys in African (Grimm, Knorringa, and Lay 2012; Mead and Liedholm 1998) and other countries (de Mel, McKenzie, and Woodruff 2008 for Sri Lanka; Djankov and others 2005 for the Russian Federation; Djankov and others 2006 for China). These studies provided very useful analyses on the dynamic decision of becoming the self-employed and microenterprise owners within the specific context of the economy.

This paper builds on previous literature and uses panel data sets from 12 developing countries across several regions and income levels to investigate the determinants of transitions into and out of selfemployment. We first analyze transition matrixes between employment statuses to outline patterns of labor mobility at the aggregate level. Next, we examine the microeconomic determinants of transitions into and out of self-employment and within self-employment. Finally, we classify individuals as particular worker "types"- out of the labor force (OLF), unemployed, own-account worker, employer, or wage employee - based on observable characteristics such as age, education, and the locality of residence rather than on actual employment status. We then examine how self-employed workers differ from or resemble workers in other employment statuses - thus indicating which own-account workers might have the similar characteristics to become employers versus wage employees.

In general, our analysis suggests that transitions in and out of labor markets and changes in employment statuses are frequent. For example, for countries in our sample with a one-year panel span, we find that close to 30 percent of individuals switched between employment statuses. Turnover rates are generally greater for non-agricultural self-employed workers, particularly for employers, as 
compared to wage employees. However, a large part of the observed mobility comprises moves into and out of the labor force. Labor mobility decreases considerably when examining only transitions between jobs. Transitions into employer or wage employee status from own-account work are limited.

Our findings suggest that age, education, and economic sector are key determinants in entry and exit from self-employment and movements within self-employment. For example, own-account workers who become employers tend to be older and better educated than those who switch to wage employment or those who remain own-account workers. It is not very common for individuals to leave wage employment for self-employment, except among older male workers with higher education who move from wage employment to become employers.

The analysis of worker types shows that about a third of own-account workers, on average, share common characteristics with employers. The proportion of workers who resemble employers is generally higher among own-account workers than among wage employees. Moreover, the share of own-account workers who resemble employers seems higher in the upper-middle-income countries than the lower-income countries in our sample. This finding suggests that own-account workers, particularly in low-income countries, are likely to be subsistence entrepreneurs; whereas own-account workers in higher-income countries may have a greater potential to become employers.

The paper is organized as follows. Section 2 describes the surveys and data used for this study and highlights some descriptive statistics of the sample. Section 3 presents the methodology applied to conduct the three types of analysis mentioned above-aggregate labor mobility, individual determinants of transition in and out of self-employment, and worker types. The next three sections present the study results. Section 7 concludes with a discussion of the general findings and their implications.

\section{Data}

This study employs panel data from 12 developing countries (see appendix A). The sample includes four Latin American countries (Argentina, Brazil, Chile, and Mexico), two East Asian countries (Indonesia and the Philippines), three African countries (South Africa, Tanzania, and Uganda), two European countries (Moldova and the Russian Federation), and one South Asian country (Pakistan). The countries were selected based on the availability of panel data. The wide coverage of regions allows common features in the dynamics of labor markets to be identified, yet it also reveals great heterogeneity in the determinants of employment status across countries. The household surveys 
provide demographic information such as age, education, and gender; as well as information on employment status, household characteristics, and residence location. ${ }^{1}$

The scope, frequency, structure, content, and availability of data differ across the surveys. To address these differences, the variables were carefully harmonized across the surveys, and some of the analysis was conducted separately for each country. ${ }^{2}$ To account for differences in frequency of data collection - the Latin American countries had monthly and quarterly observations available, while other country surveys were conducted at intervals exceeding two years - data were annualized when surveys were conducted more than once a year. Because some data sets were based on a rotational panel structure tracking only a subsample of individuals/households, balanced panels were constructed to ensure that the same individual appeared at a minimum of two points in time. ${ }^{3}$

Aside from OLF and unemployment, which are defined consistently across the surveys, classification of employment status varies by country and survey. ${ }^{4}$ Surveys in a few countries (Moldova, Pakistan, South Africa, Tanzania, and Uganda) separately identified workers in the agricultural sector (that is, as farmers); the remainder did not. Similarly, unpaid family work is a category included in several countries, but missing in Moldova, South Africa, and Tanzania; this is probably because it can overlap with agricultural work. Wage employment is disaggregated as informal and formal, or private and public in the various surveys. To standardize employment status across countries, and to examine transitions focusing on self-employment, we used the following five employment categories: OLF, unemployed, own-account worker, wage employee, and employer. In this categorization, agricultural workers are classified as own-account workers, and unpaid family workers are merged with the unemployed. The self-employed thus comprise own-account workers and employers (self-employed individuals who have at least one paid employee). ${ }^{5}$

Self-employment is very common in Indonesia, Moldova, the Philippines, Tanzania, and Uganda; it is less common in Latin America and the Caribbean, Russia, and South Africa (table 1). Although not

\footnotetext{
${ }^{1}$ Although finances play an important role in decisions regarding employment status, earnings data are not included here, due to limited coverage and issues of accuracy.

${ }^{2}$ For example, different sets of variables were included in the regression analysis for each country depending on data availability.

${ }^{3}$ In order to examine the dynamic decision of transitions, we focus only on individuals who are included multiple times. A caution needs to be exercised when the panel span is large due to potential attrition based on observables and unobservables. ${ }^{4}$ For some individuals in the Philippines who did not specify their job search efforts, it was not possible to determine whether they were unemployed or OLF; these people were thus classified as OLF.

${ }^{5}$ South Africa does not separate employers from own-account workers. To capture this distinction, we used ownership of a business and business equipment to define individuals as employers.
} 
shown in the table, the share of agricultural workers among the self-employed is high in Moldova (85 percent of the self-employed), Pakistan (50 percent), Tanzania (72 percent), and Uganda (75 percent). ${ }^{6}$

Among self-employed workers, the proportion of employers varies widely. In Indonesia and Russia, close to half of the self-employed are employers; in contrast, less than 2 percent of those selfemployed in Moldova and the Philippines are employers. The proportion of employers among the selfemployed is generally greater for men than women in all countries except Pakistan. Given that female labor market activities are quite limited in Pakistan, it is possible that this disparity is explained by a very small number of highly motivated female workers entering the labor market to undertake entrepreneurial activities. The share of employers among the non-agricultural self-employed is slightly over 20 percent for men and less than 10 percent for women in Tanzania and Uganda; in Pakistan, 5 percent of men, and 10 percent of women, among the non-agricultural self-employed are employers. ${ }^{7}$

General demographic characteristics by employment status are in line with Gindling and Newhouse (2014). In general, self-employed workers are older than individuals in the other - employment categories. Employers and wage employees are the most educated, and OLF individuals and the unemployed are generally the least educated. Wage employees are more likely to be in industry, while the self-employed are most likely to be in agriculture. Employment in the service sector is quite common for both wage employees and the self-employed. Self-employed workers, particularly employers, are more likely than wage employees to be a male head of household.

\section{Methodology}

\subsection{Aggregate Mobility}

The patterns of worker transition across different employment categories can be used to gauge the level of labor mobility, particularly the frequency of movements in and out of self-employment. We focus on two types of transition matrixes. The first is the simple (unadjusted) transition probability matrix, where entry represents the probability of shifting from status $i$ to $j, P_{i j}$, over the span of the panel data.

$$
p_{i j}=\operatorname{Pr}\left(S_{t+1}=j \mid S_{t}=i\right)=\frac{\operatorname{Pr}\left(S_{t+1}=j \cap S_{t}=i\right)}{\operatorname{Pr}\left(S_{t}=i\right)}
$$

\footnotetext{
${ }^{6}$ Because not all countries specify agricultural workers separately, we have, as noted above, included them as own-account workers. When appropriate and where data are available, we discuss results separately for agricultural workers.

${ }^{7}$ Moldova is not included in this discussion since there are only a few employers observed in the data.
} 
$S_{\mathrm{t}}$ denotes the employment status at time $t$. As discussed in Maloney (1999), while $p_{i j}$ provides raw rates of transition, it is not an accurate measure for capturing the actual flows and tendencies to move from employment status $i$ to $j$ because $p_{i j}$ ignores the propensity of job destruction in status $i$ and the propensity of job creation in status $j$ affected in part by the size of each status. For instance, the transition probability into a status where there are more opportunities (larger size) would be mechanically high regardless of individual choices and characteristics. In order to capture changes in the size of each status, and job creation and destruction rates across different statuses, the following measure is adopted. ${ }^{8}$

Let $D_{i j}$ reflect the likelihood that leavers of status $i$ due to job destruction in employment status $i$ move to status $j$; this is expressed as

$$
D_{i j}=\frac{\# \text { of individuals shifting from } i \text { to } j}{\# \text { of destructed jobs from } i}=\frac{N_{i j}}{\sum_{k \neq i} N_{i k}}=\frac{N_{i j}}{N_{i_{-}}-N_{i i}}=\frac{p_{i j}}{1-p_{i i}}
$$

where $N_{i_{-}}$represents the number of individuals in status $i$ in period $t$, and $N_{i j}$ is the number of individuals in employment status $i$ in period $t$ who move to status $j$ in period $t+1$. Therefore, given the same number of individuals transferring from status $i$ to $j, D_{i j}$ will be lower where is a higher overall outflow from status $i$.

Similarly, let $C_{i j}$ reflect the relative tendency of job creation compared to other statuses to absorb separated workers from status $i$. This is expressed as

$$
C_{i j}=\frac{\# \text { of jobs newly created from } j}{\# \text { of newly created jobs from all other than } i}=\frac{N_{-j}-N_{j j}}{\sum_{k \neq i}\left(N_{-k}-N_{k k}\right)}=\frac{p_{-j}\left(1-q_{j j}\right)}{\sum_{k \neq i} p_{-k}\left(1-q_{k k}\right)}
$$

where $q_{i j}=1-p_{i j}$, indicating the probability that the original status is $i$ given that the terminal status is $j$. We have $q_{i j}=\operatorname{Pr}\left(S_{t}=i \mid S_{t+1}=j\right)=\frac{\operatorname{Pr}\left(S_{t+1}=j \cap S_{t}=i\right)}{\operatorname{Pr}\left(S_{t+1}=j\right)}$, and $\mathrm{p}_{-\mathrm{j}}=\frac{\mathrm{N}_{-\mathrm{j}}}{\sum_{k} N_{-}}$.

Accordingly, the tendency of making transitions from status $i$ to $j$, adjusted for status size and job dynamics, can be expressed as

$$
V_{i j}=\frac{D_{i j}}{C_{i j}}
$$

\footnotetext{
${ }^{8}$ See Duryea and others (2006) for a similar approach.
} 
This adjusted transition matrix provides a unitless measure of tendency of transition, which is comparable across different groups as well as different countries.

\subsection{Individual Heterogeneity}

In addition to the patterns of aggregate mobility captured by the transition matrixes described above, we examine how individual characteristics affect labor market transitions. We use a standard multinomial logit model to estimate

$$
\log \frac{p_{i j}}{p_{i b}}=X_{i}^{\prime} \beta_{j}
$$

where $b(\neq j)$ is the base employment status, $X_{i}$ presents the individual characteristics at status $i$, and $\beta_{j}$ captures the effects of each characteristic in determining the transition.

We estimate three multinomial logit models, each corresponding to a group defined by base period employment status: (1) own-account workers, (2) wage employees, and (3) OLF individuals. In each case, the likelihood of transitioning into a different employment status is estimated using the group's base period employment status as a base outcome. Given that not all variables are available for estimation for all countries, we begin with a parsimonious specification for the estimation using pooled data from all 12 countries, and sequentially expand the set of variables. That is, using pooled data, the models are estimated utilizing information found in all 12 countries in our sample. ${ }^{9}$ The base specification includes individual characteristics of interest (age, age squared, and education) as well as location (urban/rural), changes in local unemployment rates, and country dummies. ${ }^{10}$ Next, for the variables that are available only for a subset of countries - e.g., head household, marital status, sector of activity, household size - we estimate each model by adding the variable of interest to the base specification and using the pooled data from countries where the variable is available. Hence, each of the three models is estimated once with the base specification and again for each of the variables with limited availability. Given the marked differences of labor mobility by gender, we estimate separate models for men and women for all these specifications.

\footnotetext{
${ }^{9}$ When pooling data, different numbers of observations available from each country and different sampling weights in each country can be an issue. Using the number of observations from each country as a weight and conducting weighted regressions can partially address the over/under representation of some individuals and countries. However, the weighted regressions yield results similar to those obtained from unweighted regressions. Therefore, we report the results from unweighted regressions for ease of interpretation.

${ }^{10}$ When examining a general pattern of transitions in and out of self-employment and within self-employment with a pooled sample from all 12 countries, we add country dummies. When conducting country-specific regressions for the type analysis, we add regional dummies.
} 


\subsection{Worker Type}

Worker type captures the employment status or statuses most strongly associated with an individual based on the individual's demographic and other observable attributes, regardless of actual employment status. Several recent studies investigate worker type to assess the similarities and differences between workers in different employment statuses. For instance, de Mel, McKenzie, and Woodruff (2008) use various measures of worker characteristics and conclude that own-account workers in Sri Lanka differ from the employer type. Grimm, Knorringa, and Lay (2012) analyze selfemployed workers in seven West African countries. They find that a substantial proportion of unsuccessful entrepreneurs share characteristics with successful entrepreneurs - they refer to these workers as "constrained gazelles"-_. ${ }^{11}$ Similarly, based on a large cross-section of 98 developing countries, Gindling and Newhouse (2014) find that many own-account workers share characteristics with employers.

In line with these studies, we investigate worker types for all employment statuses. We define type in relation to the predicted probability of transitioning into a given state. For instance, for each individual, we predict the probability of him or her becoming a wage employee $\left(\hat{P}_{\text {wage }}\right)$. An individual is identified as being a wage employee type if the predicted probability exceeds a threshold as follows:

$I_{\text {wage }}=\left\{\begin{array}{l}1 \text { if } \hat{P}_{\text {wage }} \geq P_{\text {wage }}^{*} \\ 0 \text { if } \hat{P}_{\text {wage }}<P_{\text {wage }}^{*}\end{array}\right.$,

where $I_{\text {wage }}$ is an indicator of wage employee type.

Two methods are used to select the threshold $P_{w a g e}^{*}$. First, following Grimm, Knorringa, and Lay (2012) and Gindling and Newhouse (2014), the $P_{\text {wage }}^{*}$ is set so that the mean $\hat{P}_{\text {wage }}$ among the latent wage employees (those who are found to be wage type but who are not actually wage employees) is equal to mean $\hat{P}_{w a g e}$ among actual wage employees. The second method is to set $P_{w a g e}^{*}$ so that the proportion of individuals identified as wage employee type $\left(I_{\text {wage }}=1\right)$ is equal to the observed proportion of actual wage employees found in the data. For instance, if the share of wage employment is 30 percent among the employed, $P_{\text {wage }}^{*}$ is set so that the top 30 percent of individuals ranked by the propensity score of being wage employees are considered as wage employee type. The methods are applied to set the threshold for each employment status.

\footnotetext{
${ }^{11}$ The study defines the top 10 percent performers as "successful" entrepreneurs based on capital and returns as performance measure.
} 
The predicted probability of an individual being in a particular employment status (which determines worker type) varies with the relative size of each employment status within that individual's economy. The share of employer type workers among own-account workers can be greater in Mexico than Pakistan, for instance, simply due to the larger size of the employer status in Mexico than Pakistan. Therefore, without adjustment, the proportion of individuals who "look like" a certain worker type will not be comparable across countries. In attempting to make the results of different countries more comparable, we present normalized distributions of each worker type by dividing the proportion of each predicted worker type within an employment status by the realized market share of each type for the whole economy. For instance, to make this adjustment, we take the share of employer type workers among own-account workers divided by the average market share for employer type in that economy.

\section{Aggregate Mobility}

\subsection{Simple Transition Matrixes}

Overall, there are considerable changes in employment status over time (table 2). Close to one-third of individuals (about 33 and 30 percent of men and women, respectively) change employment status over time. ${ }^{12}$ In general, own-account workers are less likely than wage employees to remain in the same employment status, which suggests their greater mobility or higher turnover in their activities.

When only focusing on transitions among working individuals (between own-account work, employer, and wage employment), mobility is substantially lower: about 16 percent of male and 8 percent of female workers change employment status. This suggests that many changes in employment status are due to leaving the labor force or becoming unemployed as opposed to taking different forms of employment while remaining employed.

This finding - that mobility is largely due to exiting the labor market as opposed to moving to different forms of employment - is particularly true for own-account workers, as compared to wage employees or employers. The share of male own-account workers who exit the labor force is 10 percent, compared to 7 percent for wage employees and 5 percent for employers. This pattern is even more pronounced among women: the share of female own-account workers who leave the labor force is 27 percent, compared to 16 percent and 19 percent for wage employees and employers, respectively. The

\footnotetext{
${ }^{12}$ These percentages should be read with caution as they are calculated over different spans. When the proportion of those who change employment status is calculated based on the 8 countries out of 12 that have a one-year span, the average percentage drops to 28 .
} 
greater incidence of exiting the labor market without transitioning into other forms of employment among own-account workers may signal the precariousness of their activities, particularly for women.

There are some transitions to employer status among own-account workers, but the likelihood of such a transition is relatively small. However, downgrading from employer to own-account worker is more common. Among men, the probability of transitioning from own-account work to employer is about 7 percent, while the probability of employers becoming own-account workers is 21 percent. The corresponding figures for women are 3 and 24 percent, respectively, suggesting greater difficulties for women.

In contrast to wage employees, employers who change employment status tend to turn to own-account work rather than leave the labor market. Male employers have a 21 percent probability of transitioning to own-account work and a 5 percent probability of leaving the labor force; male wage employees are as likely to move to own-account work as to exit the labor force ( 7 percent). ${ }^{13}$ This higher reliance on own-account work by employers indicates a closer relationship between them and own-account workers than between wage employees and own-account workers.

There is considerable heterogeneity in labor mobility across countries (figure 1). When only focusing on those who change jobs as opposed to moving in and out of the labor force or unemployment, Russia and South Africa show substantially low mobility. In both of these countries, wage employment is dominant, and there is a very small self-employed population. Across all countries, a striking gender difference is noted, with female workers having substantially less mobility than their male counterparts.

\subsection{Adjusted Transition Matrixes}

\section{Moves of Jobless Individuals}

It is much less likely for individuals to move from OLF or unemployment to own-account work as opposed to wage employment (table 3). This finding suggests that own-account work is not necessarily a frictionless labor market entry point or a default choice when wage employment is not available. ${ }^{14}$ OLF workers tend to enter the labor market through unemployment or wage employment. This pattern is observed in almost all sample countries, although the extent to which labor market entry takes place through unemployment versus wage employment varies by country (figure 2). Similarly, among the

\footnotetext{
${ }^{13}$ The comparable figures for females are less clear-cut: female employers have a 24 percent probability of transitioning to own-account work and a 19 percent probability of leaving the labor force; female wage employees have a 4 percent probability of moving to own-account work versus a 16 percent probability of leaving the labor force.

${ }^{14}$ Bennett and Estrin (2007) suggest that individuals enter own-account work because entry costs are lower.
} 
unemployed, many individuals either leave the labor market (discouraged) or enter wage employment. This finding is also consistent for all countries.

\section{Moves of Own-Account Workers}

While the unadjusted transition matrixes show that actual flows from own-account work to employer status are small, the tendency to move from own-account worker to employer is substantial when size of employer status is taken into consideration. Similarly, although the actual flows of own-account workers into wage employment are greater than their flows to employer status, the adjusted transition matrixes suggest that the tendency to shift from own-account worker to employer is much greater than the shift to wage employment (table 3). Further, with only a few exceptions, own-account workers have a greater tendency to become employers across entire countries studied here (figure 3 ). ${ }^{15}$ No significant gender difference is observed, except that female own-account workers are more likely to leave the labor market rather than transition into wage employment.

\section{Moves of Employers}

In line with the findings from the unadjusted transition matrixes, employers tend to scale down to ownaccount workers (table 3), which suggests that business success is not guaranteed. At the same time, transitions from employer to wage employee are also common. For instance, women in the Philippines and Tanzania, and men in South Africa, are more likely to transition from employers to wage employees, which suggests that the latter employment status may offer better opportunities (figure 4).

\section{Moves of Wage Employees}

As discussed above, separation rates among wage employees are relatively small: most wage employees remain wage employees. Those who do not tend to exit the labor force; this is particularly true of women (table 3).Across the countries studied, there seems to be no single dominant status that absorbs wage employees who change employment status (figure 5).

\section{Factors Driving Transitions into or out of Self-Employment}

This section looks at the determinants of entry into and exit out of the two self-employment statuses: own-account worker and employer. In so doing, and using the methods described above, we focus on the movements of own-account workers, wage employees, and those outside the labor force. We

\footnotetext{
${ }^{15}$ Note that in the country-specific analysis of transition, non-agricultural own-account workers in Pakistan, Tanzania, and Uganda are excluded.
} 
discuss the general patterns emerging from pooled regressions and highlight some country-specific heterogeneity.

\subsection{Exit Flows from Self-Employment}

With respect to age and education, a few distinct patterns emerge (table 4). First, being younger and having less education are associated with exiting own-account work by becoming unemployed or leaving the labor market. That those with higher education are less likely to move into OLF or unemployment is far more evident for women. Second, own-account workers who become employers tend to be older, while those who transition to wage employees are younger. Third, those who leave own-account work for wage employment or to become employers tend to be better educated than those who remain own-account workers. Secondary and tertiary education is particularly strongly associated with shifting from an own-account worker to become an employer.

These overall patterns with respect to age and education in determining transitions out of own-account work are observed across most countries, although the magnitude of the marginal effects varies widely (figure 6). Exceptions include Ugandan females, among whom young workers are more likely to become employers than their older counterparts. In fact, the pattern of youth moving from ownaccount to wage employment and older individuals moving from own-account work to become employers is muted among African countries in general, where the age difference is either insignificant or unclear. Given that youth in Africa tend to start working in the labor market and to form their own households at an earlier age than in other parts of the world, the differences between younger and older individuals in terms of maturity, labor market experience, and household responsibilities may not be as stark as elsewhere. An exception to the general education pattern exists in Argentina, Chile, and Pakistan, where male workers with more education are less likely to move to wage employment than elsewhere.

The results also indicate that workers in rural areas are less likely to exit from own-account work (table 4). This may reflect a general lower degree of labor mobility for own-account workers in rural areas due to limited opportunities. Particularly, moving from own-account work to wage employment is less frequent among rural residents. There is a consistent pattern of rural own-account workers being less likely to move into wage employment with little variation across countries. The transitions out of own-account work are pro-cyclical for men that movements to other working states-particularly to becoming an employer - are less frequent during economic downturns; such cyclicality is less evident among women. 
In addition, variables capturing a person's immediate social capital and household responsibilities (that is, head of household, size of household, marital status) matter in determining exit from own-account work. An individual's being the head of the household, and likely its main bread winner, reduces the likelihood of his or her exiting own-account work to shift to OLF or unemployment status; this is true for both men and women, reflecting that they have less flexibility with regard to interruptions in income. While male household heads are more likely to become an employer than are other members of the household, female household heads tend to turn to wage employment from own-account work. Being married has a similar effect on men as being head of household: married male own-account workers are less likely to become unemployed and exit the labor force less often, and are more likely to become employers. Marital status has a negative association with work for women. Married women tend to exit the labor force or become unemployed, or remain own-account workers rather than become wage employees; these choices are probably due to family duties and responsibilities. Having more household members to rely on seems to enable greater mobility, particularly regarding wage employment for males and employer status for females.

Finally, working in the agriculture sector is associated with a shift from own-account work to employer status for men, and from own-account work to unemployment for women. However, country-specific analysis suggests that the effect of working in agriculture on the exit decision from own-account work is not homogeneous.

\subsection{Entry into Self-Employment}

\section{Movement from OLF to Self-Employment}

The results from the pooled multinomial logit models for OLF individuals are shown in table 5, and the country-specific estimates of the marginal effects of the main variables are shown in figure 7.

Overall, the results from pooled models indicate that entry into the labor force increases with age, and that older individuals tend to enter the labor force most often through self-employment (both through own-account worker and employer statuses). The country-specific models paint a consistent picture, showing that young individuals have fewer tendencies to enter labor markets as own-account workers. While many programs aim to promote youth entrepreneurship and business setup, own-account work is not a common entry point to the labor market for young individuals - rather, they are most likely to enter as wage employees.

Those with higher education, particularly men, are less likely to enter the labor market through ownaccount work. Instead, they tend to move to wage employment or to being an employer when they 
enter the labor market. Those who enter as an employer tend to be better educated than those who enter through wage employment; the education difference between those two statuses is greater for men than for women. Country-specific analysis confirms that higher education is less associated with labor market entry through own-account work, but there is substantial heterogeneity. While male workers in Brazil, Indonesia, the Philippines, and Uganda likely drive the overall pattern, the education difference is muted in other countries and for females.

The likelihood of entering the labor market from the OLF status is greater for those living in rural areas than those in urban areas, with the most frequent entry point being own-account work. This general finding suggests that there may be a smaller entry barrier for own-account work in rural areas. The marginal effects of rural areas are statistically significant among males in Indonesia, Mexico, Moldova, Pakistan, and the Philippines; they are large, but insignificant, in Tanzania and Uganda.

When it comes to the association between unemployment rates and labor market entry, it is expected that workers remain OLF or unemployed during economic downturns. If they choose to enter the market despite the bad economy, they are expected to choose an option with a smaller entry barrier. The results indicate that during economic downturns, individuals are indeed likely to remain OLF or to experience unemployment even if they enter. Transitioning into own-account work is, however, contrary to expectation, no more prevalent than other options. This finding suggests that own-account work is not an automatic alternative for wage employment as an entry point to the labor market during economic downturns.

Household heads have a greater tendency to enter the labor force generally, most often through selfemployment (own-account work for males, and becoming employers or own-account workers for females). This tendency again likely captures the greater responsibility of a breadwinner to provide an uninterrupted income flow. Married people also tend to enter the labor force through own-account work; married males are even more likely to stay outside the labor force than to enter it through wage work. The estimated effects of household size on transition for those outside the labor force are not as strong as those for own-account workers.

\section{Movement from Wage Employment to Self-Employment}

The results from the pooled multinomial logit models for wage employees are shown in table 6 , and the country-specific estimates of the marginal effects of the main variables on the likelihood of transitioning from wage employment to own-account work are presented in figure 8 . 
There are less clear patterns among wage employees in terms of transitions into self-employment. Transitioning from wage employment to self-employment increases with age, but this is observed only for men, both in the pooled and country-specific analyses. ${ }^{16}$ A common notion is that wage employees wait until they accumulate sufficient start-up capital before setting up a business. However, in many cases, women tend to be secondary earners and have little control over a household's financial resources, particularly regarding business activities; this might be a reason age is not strongly associated with women's transitioning from wage employment to self-employment. In addition, as women get older, they may have reduced child care duties and thus have less interest in flexibility that self-employment offers as compared to wage employment, offsetting the general tendency of older individuals establishing a business.

Compared to those who remain wage employees, those who become own-account workers tend to be less educated. This result is fairly consistent across countries for both men and women. As expected, those workers with a tertiary education are the least likely to move to own-account work, followed by those with a secondary education.

Wage employees in rural areas tend to move out of wage employment most often, with the larger probability of moving into own-account work and, to a slightly lesser degree, into unemployment. The country-specific results show that the effect of residing in rural areas on the likelihood of moving from wage employment to own-account work is quite large, particularly in Moldova, Tanzania, and Uganda. Male wage employees in rural areas are also more likely to become employers. Wage employees in the agricultural sector exhibit a similar pattern, exiting wage work more often relative to workers in other sectors. These results suggest that wage employment in rural areas or in the agricultural sector may be less stable and possibly seasonal — in that workers may lose their jobs more often (moving into OLF or unemployment status) and seek other earnings opportunities (moving into own-account work or becoming an employer). The positive effects of the agriculture sector on the likelihood of transitioning from wage employment to own-account work are statistically significant for men in almost all countries.

The results for variables related to immediate social capital are varied. As found in other cases, workers who head households will tend to stay in wage work over being unemployed or exiting the labor force. However, the results do not provide evidence that being the head of the household has an effect on transitions from wage work into self-employment. Also, similar to other cases, having the support of other household members increases the likelihood that an individual will enter

\footnotetext{
${ }^{16}$ In line with the discussion above regarding African youth, Tanzania and Uganda are the exceptions; here, movements from wage employment to own-account work are more frequent among young workers.
} 
unemployment or leave the labor force. Results do not show a very strong effect of household size on moving from wage work to own-account work. Similarly, married female wage employees do not exhibit particularly strong patterns; among married men, we find an increase in the likelihood of becoming own-account workers. However, there is limited significance when considering countrylevel results.

\section{Who Are the Self-Employed and How Do They Compare to Other Workers?}

One important argument in the recent literature is that own-account workers becoming employers by growing their business is not common, and that own-account workers are indeed considered a distinct group from employers. ${ }^{17}$ This view suggests that policy efforts to try to transform own-account workers into employers may not be effective. This section examines this claim and analyzes the similarities and differences between workers in different employment statuses in our sample, based on observable characteristics.

The results show that there is a non-negligible share of employer type workers among own-account workers: about 36 and 31 percent, on average, for men and women, respectively (table 7). ${ }^{18}$ Additionally, in higher-income countries in our sample, such as Argentina, Brazil, and Mexico, a greater proportion of own-account workers have similar characteristics to employers than in lowerincome countries such as the Philippines, Tanzania, and Uganda. ${ }^{19}$ The proportion of workers classified as employer type is larger among own-account workers than among wage employees in most countries. On average, the shares of workers of employer type among wage employees are 29 and 26 percent for men and women, respectively. There are a few cases where the proportion of latent employers is larger among wage employees than among own-account workers. ${ }^{20}$

The results from adjusting for the size of the respective market shares of each worker type confirm the extent to which own-account workers have a greater similarity to employers than to wage employees in most countries (figure 9). In Mexico, for instance, male workers of wage employee type are underrepresented among own-account workers by 20 percent, while the share of employer types

\footnotetext{
${ }^{17}$ See de Mel, McKenzie, and Woodruff (2008b); Schoar (2009).

${ }^{18}$ As discussed in the methodology section, we first ran multinomial regressions for each country separately by gender, obtained the predicted probability of transitioning into different employment states, and defined types of workers. Given the static nature of OLF workers and their differences, we used the sample of workers who were already in the labor force in the base period.

${ }^{19}$ Exceptions include Chile and South Africa, where the share of workers of employer type is low for their income level.

${ }^{20}$ Examples include the Philippines, South Africa, and Uganda.
} 
among own-account workers is about 30 percent higher than their average market share. ${ }^{21}$ This indicates that Mexican own-account workers have a greater similarity to employers than wage employees to employers by 36 percent. On average, own-account workers look more like employers than wage employees by 17 percent.

The reverse association was investigated in a similar manner, examining how closely employers resemble own-account workers (figure 10). ${ }^{22}$ Among employers, a slightly larger share of workers are classified as being own-account worker type rather than wage employee type. On average, employers look more like own-account workers than wage employees by 8 percent. As an example, Indonesian female employers look almost twice as similar to own-account workers as to wage employees; among female employers in the Philippines, wage employee type is four times more overrepresented than own-account workers. The same results on the order of similarity are obtained regardless of method used to define worker type.

In summary, many own-account workers look like employers and vice versa. However, this similarity between the two groups may be due to the frequent downsizing of employers, and not necessarily imply the growth potential of own-account workers. It is important to recognize the heterogeneity among own-account workers and employers, and to design policies accordingly.

\section{Conclusions}

This paper has examined labor market transitions, the determinants of these transitions, and the similarities in the characteristics of workers in different employment statuses with a particular focus on self-employment.

Our analysis, based on panel data from 12 developing countries, shows that self-employment is a dynamic state and that self-employed workers are a heterogeneous group. At one end, younger and less educated own-account workers tend to leave the labor force, most likely due to the precariousness of their activities. At the other end, older and better educated own-account workers-particularly those in urban areas - are more likely to become employers or, to a lesser extent, to transition into wage employment.

\footnotetext{
${ }^{21}$ Figure 9 defines worker type based on first methodology as discussed in Section 3.3. A similar figure using the second methodology is found in figure B1 in appendix B.

${ }^{22}$ Figure 10 defines worker type based on first methodology as discussed in Section 3.3. A similar figure using the second methodology is found in figure B2 in appendix B.
} 
The analysis also brought to light the role of own-account work as an entry point into the labor market and as a coping mechanism. In contrast to the common view that own-account work may be an easy and frictionless labor market entry point, it is the least frequent option selected among those who are OLF. The main path from OLF status is wage employment. Exiting wage employment for ownaccount work is not common, particularly among better educated workers. Wage employees tend to exit the labor force or to become unemployed rather than go into own-account work, even during economic downturns.

While there is heterogeneity across countries, in general, there is a significant proportion of ownaccount workers who share similar characteristics with employers. This pattern is more prominent in higher-income countries, a finding in line with Gindling and Newhouse (2014) and Grimm and others (2012). Moreover, the similarity between own-account workers and employers seems stronger than that between employers and wage employees, probably due to frequent transitions from employer to own-account downsizing.

Overall, the results from the analysis only paint a partial picture of the dynamics around selfemployment and should be interpreted with caution. There are important data limitations that, for instance, precluded an analysis of how different types of skills affect labor market transitions. Another gap in this analysis of transitions is earnings and other indicators of the quality of self-employment, which are important determinants of the decision to enter or exit self-employment. Future research on labor mobility could greatly benefit from more detailed panel data. 


\section{References}

Blanchflower, David and Andrew Oswald (1998), “What Makes an Entrepreneur?”Journal of Labor Economics 16(1): pp. 26-60.

Bosch, Mariano, and William F. Maloney. 2010. "Comparative Analysis of Labor Market Dynamics Using Markov Processes: An Application to Informality." Labour Economics 17 (4).

de Mel, S., D. McKenzie, and C. Woodruff. 2008. "Who Are the Microenterprise Owners: Evidence from Sri Lanka on Tokman v. de Soto.” In: Lerner, J., and A. Schoar (eds). International Differences in Entrepreneurship. Chicago: University of Chicago Press: pp. 63-87.

Djankov, Simeon, Edward Miguel, Yingyi Qian, Gérard Roland, and Ekaterina Zhuravskaya. 2005. “Who Are Russia's Entrepreneurs?” Journal of the European Economic Association 3 (2-3): 111.

Djankov, Simeon, Yingyi Qian, Gérard Roland, and Ekaterina Zhuravskaya. 2006. "Who Are China's Entrepreneurs?" American Economic Review 96 (2): 348-52.

Duryea, Suzanne, Gustavo Marquéz, Carmen Pagés, and Stefano Scarpetta. 2006. "For Better or for Worse? Job and Earnings Mobility in Nine Middle- and Low-Income Economies.” In Brookings Trade Forum 2006: Global Labor Markets?, edited by Susan M. Collins and Carol Graham, 187-209. Washington, DC: Brookings Institution Press.

Fields, Gary. 1975. "Rural-Urban Migration, Urban Unemployment and Underemployment, and Job Search Activities in LDC's.” Journal of Development Economics 2: 165-88.

Fox, Louise and Thomas Pave Sohnesen (2012) "Household Enterprises in Sub-Saharan Africa: Why They Matter for Growth, Jobs, and Livelihoods” World Bank Policy Research Working Paper 6184

Gindling, T. H., and D. L. Newhouse. 2014. "Self-Employment in the Developing World." World Development. Vol. 56: 313-331.

Grimm. M., P. Knorringa, and J. Lay. "Constrained gazelles: High potentials in West Africa's Informal Economy.” World Development 40:7: (2012): 1352-1368.

Maloney, William F. 1999. “Self-Employment and Labor Turnover: Cross-Country Evidence.” Policy Research Working Paper 2102, World Bank, Washington, DC. 
Mead, Donald C., and Carl Liedholm. 1998. "The Dynamics of Micro and Small Enterprises in Developing Countries." World Development 26 (1): 61-74.

Mondragón-Vélez, Camilio, and Ximena Peña. 2010. "Business Ownership and Self-Employment in Developing Economies: The Colombian Case." In International Differences in Entrepreneurship, edited by Josh Lerner and Antoinette Schoar, 89-127. Chicago: University of Chicago Press.

Perry, Guillermo E., William F. Maloney, Omar S. Arias, Pablo Fajnzylber, Andrew D. Mason, and Jaime Saavedra-Chanduvi. 2007. Informality: Exit and Exclusion. Washington, DC: World Bank.

Schoar, Antoinette. 2009. "The Divide between Subsistence and Transformational Entrepreneurship." In Innovation Policy and the Economy, Vol. 10, edited by Josh Lerner and Scott Stern, 57-81. Chicago: University of Chicago Press. 
Table 1: Percentage Distribution of Employment Status in the Base Year by Gender

\begin{tabular}{|c|c|c|c|c|c|c|c|}
\hline \multirow[b]{2}{*}{ Country } & \multirow[b]{2}{*}{ Gender } & \multirow[b]{2}{*}{ OLF } & \multicolumn{5}{|c|}{ Self employed } \\
\hline & & & Unemployed & Own account & Employer & $\begin{array}{c}\text { Employer as } \\
\text { share of self- } \\
\text { employed }\end{array}$ & $\begin{array}{c}\text { Wage } \\
\text { employee }\end{array}$ \\
\hline \multirow{2}{*}{ Argentina } & Male & 25.3 & 6.7 & 16.5 & 4.6 & 21.8 & 46.9 \\
\hline & Female & 49.6 & 6.1 & 7.3 & 1.3 & 15.3 & 35.6 \\
\hline \multirow{2}{*}{ Brazil } & Male & 22.0 & 6.0 & 15.2 & 4.5 & 22.7 & 52.3 \\
\hline & Female & 46.3 & 7.6 & 9.4 & 1.8 & 16.0 & 34.9 \\
\hline \multirow{2}{*}{ Chile } & Male & 19.7 & 8.1 & 14.1 & 2.6 & 15.4 & 55.6 \\
\hline & Female & 47.4 & 6.5 & 7.4 & 0.5 & 6.1 & 38.2 \\
\hline \multirow{2}{*}{ Indonesia } & Male & 11.0 & 8.3 & 22.3 & 17.9 & 44.4 & 40.6 \\
\hline & Female & 40.0 & 16.7 & 14.1 & 9.9 & 41.3 & 19.3 \\
\hline \multirow{2}{*}{ Mexico } & Male & 17.8 & 6.7 & 16.0 & 5.5 & 25.7 & 54.0 \\
\hline & Female & 52.4 & 6.1 & 9.7 & 1.2 & 11.1 & 30.6 \\
\hline \multirow{2}{*}{ Moldova } & Male & 24.9 & 4.1 & 29.7 & 0.6 & 1.9 & 40.7 \\
\hline & Female & 30.3 & 2.9 & 25.5 & 0.4 & 1.4 & 40.9 \\
\hline \multirow{2}{*}{ Pakistan } & Male & 24.0 & 10.4 & 20.4 & 0.6 & 2.8 & 44.5 \\
\hline & Female & 83.8 & 8.5 & 1.2 & 0.0 & 3.1 & 6.4 \\
\hline \multirow{2}{*}{ Philippines } & Male & 23.3 & 12.3 & 27.3 & 0.3 & 1.2 & 36.9 \\
\hline & Female & 50.2 & 12.0 & 16.0 & 0.1 & 0.5 & 21.7 \\
\hline Russian & Male & 24.4 & 13.2 & 1.2 & 1.4 & 52.5 & 59.8 \\
\hline Federation & Female & 26.6 & 15.4 & 1.0 & 0.7 & 41.4 & 56.3 \\
\hline \multirow{2}{*}{ South Africa } & Male & 42.3 & 10.6 & 7.8 & 1.8 & 19.0 & 37.5 \\
\hline & Female & 51.9 & 13.6 & 9.3 & 0.8 & 8.0 & 24.4 \\
\hline \multirow{2}{*}{ Tanzania } & Male & 24.1 & 3.2 & 49.4 & 1.4 & 2.8 & 21.9 \\
\hline & Female & 32.1 & 3.5 & 55.0 & 0.9 & 1.6 & 8.6 \\
\hline \multirow{2}{*}{ Uganda } & Male & 13.7 & 2.7 & 65.0 & 4.3 & 6.2 & 14.5 \\
\hline & Female & 14.0 & 7.3 & 72.6 & 1.6 & 2.1 & 4.5 \\
\hline
\end{tabular}

Source: Labor force and household surveys from respective countries; see appendix A. 
Table 2: Unadjusted Transition Matrixes by Gender

\begin{tabular}{|c|c|c|c|c|c|c|c|c|c|}
\hline \multicolumn{7}{|c|}{ A. Unadjusted transition matrices } & \multicolumn{3}{|c|}{ B. Shares } \\
\hline $\begin{array}{l}\text { Employment } \\
\text { Status }\end{array}$ & Initial Size & OLF & $\begin{array}{c}\text { Un- } \\
\text { employed }\end{array}$ & $\begin{array}{c}\text { Own } \\
\text { account }\end{array}$ & $\begin{array}{c}\text { Wage } \\
\text { employee }\end{array}$ & Employer & $\begin{array}{c}\% \text { of } \\
\text { individuals } \\
\text { who remain in } \\
\text { employment } \\
\text { status } \\
\end{array}$ & $\begin{array}{c}\% \text { of } \\
\text { individuals } \\
\text { who change } \\
\text { employment } \\
\text { status }\end{array}$ & $\begin{array}{c}\% \text { of } \\
\text { workers } \\
\text { who change } \\
\text { employment } \\
\text { status }\end{array}$ \\
\hline & \multicolumn{6}{|c|}{$\underline{\text { Male }}$} & \multicolumn{3}{|c|}{$\underline{\text { Male }}$} \\
\hline OLF & $21.8 \%$ & 0.659 & 0.093 & 0.070 & 0.168 & 0.009 & $14.4 \%$ & $7.4 \%$ & n.a. \\
\hline Unemployed & $8.1 \%$ & 0.195 & 0.335 & 0.109 & 0.331 & 0.030 & $2.7 \%$ & $5.4 \%$ & n.a. \\
\hline Own account & $18.4 \%$ & 0.096 & 0.044 & 0.614 & 0.180 & 0.066 & $11.3 \%$ & $7.1 \%$ & $6.4 \%$ \\
\hline Wage employees & $46.5 \%$ & 0.074 & 0.055 & 0.073 & 0.775 & 0.023 & $36.0 \%$ & $10.5 \%$ & $6.4 \%$ \\
\hline Employer & $5.2 \%$ & 0.049 & 0.038 & 0.213 & 0.174 & 0.527 & $2.7 \%$ & $2.5 \%$ & $2.9 \%$ \\
\hline \multirow[t]{2}{*}{ Total } & $100 \%$ & 0.217 & 0.083 & 0.184 & 0.462 & 0.054 & $67.1 \%$ & $32.9 \%$ & $15.7 \%$ \\
\hline & \multicolumn{6}{|c|}{$\underline{\text { Female }}$} & \multicolumn{3}{|c|}{ Female } \\
\hline OLF & $50.4 \%$ & 0.783 & 0.066 & 0.052 & 0.094 & 0.006 & $39.4 \%$ & $11.0 \%$ & n.a. \\
\hline Unemployed & $8.2 \%$ & 0.385 & 0.327 & 0.087 & 0.185 & 0.016 & $2.7 \%$ & $5.5 \%$ & n.a. \\
\hline Own account & $11.5 \%$ & 0.266 & 0.056 & 0.554 & 0.093 & 0.031 & $6.4 \%$ & $5.1 \%$ & $3.4 \%$ \\
\hline Wage employees & $28.4 \%$ & 0.161 & 0.047 & 0.038 & 0.748 & 0.007 & $21.2 \%$ & $7.1 \%$ & $3.0 \%$ \\
\hline Employer & $1.5 \%$ & 0.187 & 0.111 & 0.237 & 0.099 & 0.366 & $0.5 \%$ & $0.9 \%$ & $1.2 \%$ \\
\hline Total & $100 \%$ & 0.507 & 0.082 & 0.113 & 0.283 & 0.015 & $70.3 \%$ & $29.7 \%$ & $7.7 \%$ \\
\hline
\end{tabular}

Notes: All 12 countries are pooled to generate the transition matrixes; Each row indicates employment statuses in the base period, and each column in transition matrixes indicates employment status in the next period; Initial size indicates the percentage of individuals who were in the particular employment status in the base period; Unadjusted transition matrix rows sum to 1; The likelihood of staying in the same employment status conditional on the base year employment status is highlighted in grey; The proportion of those who remain in their employment status is the product of highlighted diagonals and initial size. 


\section{Table 3: Adjusted Transition Matrixes by Gender}

\begin{tabular}{|c|c|c|c|c|c|}
\hline Employment Status & OLF & Unemployed & Own account & Wage employee & Employer \\
\hline & & & $\underline{\text { Male }}$ & & \\
\hline OLF & 7.166 & 1.261 & 0.775 & 1.200 & 0.253 \\
\hline Unemployed & 1.145 & 2.444 & 0.650 & 1.275 & 0.441 \\
\hline Own account & 0.928 & 0.522 & 6.010 & 1.138 & 1.628 \\
\hline Wage employee & 1.043 & 0.966 & 1.050 & 7.181 & 0.834 \\
\hline \multirow[t]{2}{*}{ Employer } & 0.445 & 0.432 & 1.967 & 1.040 & 12.229 \\
\hline & & & Female & & \\
\hline OLF & 6.102 & 1.038 & 0.941 & 1.073 & 0.508 \\
\hline Unemployed & 1.257 & 2.150 & 0.664 & 0.885 & 0.604 \\
\hline Own account & 1.351 & 0.577 & 6.599 & 0.694 & 1.757 \\
\hline Wage employee & 1.283 & 0.755 & 0.703 & 8.764 & 0.611 \\
\hline Employer & 0.767 & 0.919 & 2.282 & 0.599 & 16.843 \\
\hline
\end{tabular}

Notes: All 12 countries are pooled to generate the transition matrixes; Each row indicates employment status in the base period, and each column in transition matrixes indicates employment status in the next period; Adjusted matrixes take the size of each employment status into consideration and each entry indicates V_ij, as described in Section 3.1. 
Table 4: Who Leaves Own-account Work?

\begin{tabular}{|c|c|c|c|c|c|c|c|c|}
\hline & \multicolumn{4}{|c|}{$\underline{\text { Male }}$} & \multicolumn{4}{|c|}{$\underline{\text { Female }}$} \\
\hline & OLF & $\begin{array}{c}\text { Un- } \\
\text { employed }\end{array}$ & $\begin{array}{c}\text { Wage } \\
\text { employee }\end{array}$ & Employer & OLF & $\begin{array}{c}\text { Un- } \\
\text { employed }\end{array}$ & $\begin{array}{c}\text { Wage } \\
\text { employee }\end{array}$ & Employer \\
\hline \multicolumn{9}{|c|}{ Base Specification (all 12 countries): } \\
\hline Age & $\begin{array}{c}-0.278 * * * \\
(0.014)\end{array}$ & $\begin{array}{c}-0.240 * * * \\
(0.017)\end{array}$ & $\begin{array}{c}-0.115^{* * *} * \\
(0.011)\end{array}$ & $\begin{array}{c}0.064 * * * \\
(0.014)\end{array}$ & $\begin{array}{c}-0.155^{* * *} * \\
(0.013)\end{array}$ & $\begin{array}{c}-0.082 * * * \\
(0.021)\end{array}$ & $\begin{array}{c}-0.088 * * * \\
(0.019)\end{array}$ & $\begin{array}{c}0.083 * * * \\
(0.025)\end{array}$ \\
\hline Age Squared & $\begin{array}{c}0.003 * * * \\
(0.000)\end{array}$ & $\begin{array}{c}0.002^{* * * *} \\
(0.000)\end{array}$ & $\begin{array}{c}0.001 * * * \\
(0.000)\end{array}$ & $\begin{array}{c}-0.001 * * * \\
(0.000)\end{array}$ & $\begin{array}{c}0.002^{* * *} \\
(0.000)\end{array}$ & $\begin{array}{c}0.001 * * \\
(0.000)\end{array}$ & $\begin{array}{c}0.001 * * * \\
(0.000)\end{array}$ & $\begin{array}{c}-0.001 * * * \\
(0.000)\end{array}$ \\
\hline Primary & $\begin{array}{l}-0.061 \\
(0.083)\end{array}$ & $\begin{array}{c}0.159 \\
(0.110)\end{array}$ & $\begin{array}{c}0.014 \\
(0.059)\end{array}$ & $\begin{array}{c}0.630 * * * \\
(0.076)\end{array}$ & $\begin{array}{l}-0.111 \\
(0.069)\end{array}$ & $\begin{array}{l}-0.078 \\
(0.110)\end{array}$ & $\begin{array}{c}0.011 \\
(0.113)\end{array}$ & $\begin{array}{c}0.695^{* * *} * \\
(0.142)\end{array}$ \\
\hline Secondary & $\begin{array}{l}-0.100 \\
(0.086)\end{array}$ & $\begin{array}{c}0.101 \\
(0.109)\end{array}$ & $\begin{array}{l}-0.017 \\
(0.057)\end{array}$ & $\begin{array}{c}1.024 * * * \\
(0.076)\end{array}$ & $\begin{array}{l}-0.137^{*} \\
(0.072)\end{array}$ & $\begin{array}{c}-0.280 * * \\
(0.117)\end{array}$ & $\begin{array}{l}0.185^{*} \\
(0.111)\end{array}$ & $\begin{array}{c}1.193 * * * \\
(0.144)\end{array}$ \\
\hline Tertiary & $\begin{array}{l}-0.059 \\
(0.105)\end{array}$ & $\begin{array}{c}0.048 \\
(0.138)\end{array}$ & $\begin{array}{c}0.172 * * \\
(0.068)\end{array}$ & $\begin{array}{c}1.829 * * * \\
(0.081)\end{array}$ & $\begin{array}{c}-0.497 * * * \\
(0.087)\end{array}$ & $\begin{array}{c}-0.510 * * * \\
(0.145)\end{array}$ & $\begin{array}{c}0.385^{* * *} \\
(0.121)\end{array}$ & $\begin{array}{c}1.968 * * * \\
(0.153)\end{array}$ \\
\hline Rural area & $\begin{array}{c}-0.372^{* * *} * \\
(0.082)\end{array}$ & $\begin{array}{c}-0.332 * * * \\
(0.093)\end{array}$ & $\begin{array}{c}-0.426 * * * \\
(0.056)\end{array}$ & $\begin{array}{l}-0.033 \\
(0.067)\end{array}$ & $\begin{array}{c}-0.231 * * * \\
(0.064)\end{array}$ & $\begin{array}{c}0.237 * * \\
(0.094)\end{array}$ & $\begin{array}{c}-0.362^{* * *} * \\
(0.099)\end{array}$ & $\begin{array}{l}-0.123 \\
(0.108)\end{array}$ \\
\hline $\begin{array}{l}\text { Change in } \\
\text { unemployment }\end{array}$ & $-1.442 * *$ & $4.166^{* * *}$ & $-1.212^{* *}$ & $-3.399 * * *$ & $1.356^{* * *}$ & $1.473 * *$ & 0.473 & -0.105 \\
\hline & $(0.731)$ & $(0.820)$ & $(0.561)$ & $(0.565)$ & $(0.410)$ & $(0.576)$ & $(0.608)$ & $(0.605)$ \\
\hline Constant & $\begin{array}{c}2.006^{* * *} * \\
(0.447)\end{array}$ & $\begin{array}{c}1.348 * * \\
(0.559)\end{array}$ & $\begin{array}{c}1.679 * * * \\
(0.256)\end{array}$ & $\begin{array}{c}-3.973 * * * \\
(0.342)\end{array}$ & $\begin{array}{c}1.018 * * * \\
(0.348)\end{array}$ & $\begin{array}{l}-1.022 * \\
(0.527)\end{array}$ & $\begin{array}{l}-0.255 \\
(0.448)\end{array}$ & $\begin{array}{c}-4.648 * * * \\
(0.559)\end{array}$ \\
\hline $\begin{array}{l}\text { Country } \\
\text { dummies }\end{array}$ & \multicolumn{4}{|c|}{ Yes } & \multicolumn{4}{|c|}{ Yes } \\
\hline $\begin{array}{l}\text { Number of } \\
\text { observations }\end{array}$ & \multicolumn{4}{|c|}{22,374} & \multicolumn{4}{|c|}{12,895} \\
\hline Adjusted R2 & \multicolumn{4}{|c|}{0.128} & \multicolumn{4}{|c|}{0.098} \\
\hline
\end{tabular}

Limited Availability Variables :

\begin{tabular}{lcccccccc}
\hline Household & $-0.801 * * *$ & $-1.146 * * *$ & $-0.251^{* * *}$ & $0.204 * *$ & $-0.318^{* * *}$ & $-0.781 * * *$ & $0.179 * *$ & -0.109 \\
Head & $(0.084)$ & $(0.098)$ & $(0.058)$ & $(0.098)$ & $(0.058)$ & $(0.118)$ & $(0.078)$ & $(0.123)$ \\
Married & $-0.415^{* * *}$ & $-1.078^{* * *}$ & $-0.305^{* * *}$ & $0.641^{* * *}$ & $0.217^{* *}$ & $0.476^{* * *}$ & $-0.444 * * *$ & 0.187 \\
& $(0.142)$ & $(0.142)$ & $(0.103)$ & $(0.227)$ & $(0.090)$ & $(0.144)$ & $(0.130)$ & $(0.192)$ \\
Household Size & 0.019 & $0.083^{* * *}$ & $0.023^{* *}$ & 0.023 & $0.075 * *$ & $0.052^{* * *}$ & 0.009 & $0.053^{*}$ \\
& $(0.014)$ & $(0.015)$ & $(0.009)$ & $(0.015)$ & $(0.012)$ & $(0.020)$ & $(0.019)$ & $(0.028)$ \\
Agricultural & -0.125 & -0.113 & $-0.184 * * *$ & $0.366 * * *$ & 0.040 & $0.415^{* * *}$ & 0.164 & 0.152 \\
Sector & $(0.099)$ & $(0.108)$ & $(0.066)$ & $(0.091)$ & $(0.098)$ & $(0.133)$ & $(0.142)$ & $(0.188)$ \\
\hline
\end{tabular}

Notes: Standard errors in parentheses; $* * * \mathrm{p}<0.01, * * \mathrm{p}<0.05, * \mathrm{p}<0.1$; Estimates are based on multinomial logistic regression of pooled data from countries where variables were available, using only those individuals who were own account workers in the base state. "No education" is the omitted level among education variables. Change in unemployment refers to the percentage points difference in gender and area specific unemployment rates over time. Own account work is the base category. Results reported for each of the limited availability variables come from a regression including only the base specification and the specific limited availability variable that uses pooled data from the countries where the variable was available. See appendix A for the list of countries using each of the limited availability variables. Complete results for the regressions estimated for each of the limited availability variables are available from the authors on request. 
Table 5: Who Enters Self-Employment from the Out-of-Labor-Force Status?

\begin{tabular}{|c|c|c|c|c|c|c|c|c|}
\hline & & $\underline{\mathrm{M}}$ & ale & & & FeI & nale & \\
\hline & $\begin{array}{c}\text { Un- } \\
\text { employed }\end{array}$ & $\begin{array}{c}\text { Own } \\
\text { Account }\end{array}$ & Wage & Employer & $\begin{array}{c}\begin{array}{c}\text { Un- } \\
\text { employed }\end{array} \\
\end{array}$ & $\begin{array}{c}\text { Own } \\
\text { Account }\end{array}$ & Wage & Employer \\
\hline Base Specifica & ion (all $12 \mathrm{c}$ & ountries): & & & & & & \\
\hline Age & $\begin{array}{c}0.121 * * * \\
(0.012)\end{array}$ & $\begin{array}{c}0.208 * * * \\
(0.011)\end{array}$ & $\begin{array}{c}0.104 * * * \\
(0.008)\end{array}$ & $\begin{array}{c}0.263 * * * \\
(0.033)\end{array}$ & $\begin{array}{c}0.046^{* * * *} \\
(0.007)\end{array}$ & $\begin{array}{c}0.153 * * * \\
(0.008)\end{array}$ & $\begin{array}{c}0.014 * * * \\
(0.005)\end{array}$ & $\begin{array}{c}0.273 * * * \\
(0.028)\end{array}$ \\
\hline Age Squared & $\begin{array}{c}-0.002 * * * \\
(0.000)\end{array}$ & $\begin{array}{c}-0.002 * * * \\
(0.000)\end{array}$ & $\begin{array}{c}-0.001 * * * \\
(0.000)\end{array}$ & $\begin{array}{c}-0.003^{* * * *} \\
(0.000)\end{array}$ & $\begin{array}{c}-0.001 * * * \\
(0.000)\end{array}$ & $\begin{array}{c}-0.002 * * * \\
(0.000)\end{array}$ & $\begin{array}{c}-0.000 * * * \\
(0.000)\end{array}$ & $\begin{array}{c}-0.003^{* * *} * \\
(0.000)\end{array}$ \\
\hline Primary & $\begin{array}{c}0.050 \\
(0.090)\end{array}$ & $\begin{array}{l}-0.061 \\
(0.082)\end{array}$ & $\begin{array}{c}0.241 * * * \\
(0.067)\end{array}$ & $\begin{array}{c}0.434 \\
(0.306)\end{array}$ & $\begin{array}{l}-0.044 \\
(0.053)\end{array}$ & $\begin{array}{c}-0.103^{*} \\
(0.055)\end{array}$ & $\begin{array}{c}0.151^{* * *} \\
(0.051)\end{array}$ & $\begin{array}{c}0.111 \\
(0.210)\end{array}$ \\
\hline Secondary & $\begin{array}{l}0.138^{*} \\
(0.084)\end{array}$ & $\begin{array}{c}-0.298 * * * \\
(0.083)\end{array}$ & $\begin{array}{c}0.302 * * * \\
(0.065)\end{array}$ & $\begin{array}{c}0.852 * * * \\
(0.295)\end{array}$ & $\begin{array}{l}-0.019 \\
(0.052)\end{array}$ & $\begin{array}{l}-0.019 \\
(0.057)\end{array}$ & $\begin{array}{c}0.374 * * * \\
(0.050)\end{array}$ & $\begin{array}{c}0.901 * * * \\
(0.206)\end{array}$ \\
\hline Tertiary & $\begin{array}{l}-0.032 \\
(0.099)\end{array}$ & $\begin{array}{c}-0.425^{* * * *} \\
(0.108)\end{array}$ & $\begin{array}{c}0.097 \\
(0.078)\end{array}$ & $\begin{array}{c}1.386^{* * * *} \\
(0.313)\end{array}$ & $\begin{array}{c}0.167 * * \\
(0.068)\end{array}$ & $\begin{array}{l}-0.003 \\
(0.076)\end{array}$ & $\begin{array}{c}0.717 * * * \\
(0.058)\end{array}$ & $\begin{array}{c}1.143^{* * *} \\
(0.261)\end{array}$ \\
\hline Rural area & $\begin{array}{c}0.363 * * * \\
(0.060)\end{array}$ & $\begin{array}{c}0.890 * * * \\
(0.075)\end{array}$ & $\begin{array}{l}0.089 * \\
(0.053)\end{array}$ & $\begin{array}{r}0.580^{* *} \\
(0.242)\end{array}$ & $\begin{array}{c}0.454 * * * \\
(0.044)\end{array}$ & $\begin{array}{c}0.426 * * * \\
(0.051)\end{array}$ & $\begin{array}{c}-0.157 * * * \\
(0.043)\end{array}$ & $\begin{array}{l}0.247 * \\
(0.140)\end{array}$ \\
\hline $\begin{array}{l}\text { Change in } \\
\text { unemployment }\end{array}$ & $\begin{array}{c}3.717 * * * \\
(0.613)\end{array}$ & $\begin{array}{l}-0.393 \\
(0.752)\end{array}$ & $\begin{array}{l}-0.166 \\
(0.488)\end{array}$ & $\begin{array}{l}-0.823 \\
(1.979)\end{array}$ & $\begin{array}{c}1.401 * * * \\
(0.268)\end{array}$ & $\begin{array}{c}-2.425^{* * *} \\
(0.320)\end{array}$ & $\begin{array}{c}-0.788 * * * \\
(0.262)\end{array}$ & $\begin{array}{l}-0.394 \\
(0.738)\end{array}$ \\
\hline Constant & $\begin{array}{c}-3.514 * * * \\
(0.318)\end{array}$ & $\begin{array}{c}-3.536^{* * * *} \\
(0.233)\end{array}$ & $\begin{array}{c}-2.560 * * * \\
(0.229)\end{array}$ & $\begin{array}{c}-7.953 * * * \\
(0.747)\end{array}$ & $\begin{array}{c}-2.399 * * * \\
(0.258)\end{array}$ & $\begin{array}{c}-2.925 * * * \\
(0.188)\end{array}$ & $\begin{array}{c}-2.062^{* * *} * \\
(0.245)\end{array}$ & $\begin{array}{c}-7.716^{* * *} \\
(0.607)\end{array}$ \\
\hline $\begin{array}{l}\text { Country } \\
\text { dummies } \\
\text { Number of } \\
\text { observations } \\
\text { Adjusted R2 }\end{array}$ & & 24 & 220 & & & & 559 & \\
\hline Limited Availal & mity Variab & les : & & & & & & \\
\hline $\begin{array}{l}\text { Household } \\
\text { Head }\end{array}$ & $\begin{array}{l}-0.080 \\
(0.070)\end{array}$ & $\begin{array}{c}0.334 * * * \\
(0.058)\end{array}$ & $\begin{array}{c}0.170 * * * \\
(0.051)\end{array}$ & $\begin{array}{l}-0.051 \\
(0.205)\end{array}$ & $\begin{array}{l}-0.075 \\
(0.105)\end{array}$ & $\begin{array}{c}0.479 * * * \\
(0.093)\end{array}$ & $\begin{array}{c}0.264 * * * \\
(0.075)\end{array}$ & $\begin{array}{c}1.006 * * * \\
(0.259)\end{array}$ \\
\hline Married & $\begin{array}{c}-0.247 * * * \\
(0.063)\end{array}$ & $\begin{array}{c}0.299 * * * \\
(0.082)\end{array}$ & $\begin{array}{c}-0.556^{* * * *} \\
(0.065)\end{array}$ & $\begin{array}{c}0.348 \\
(0.225)\end{array}$ & $\begin{array}{c}-0.215^{*} \\
(0.126)\end{array}$ & $\begin{array}{c}0.530 * * * \\
(0.146)\end{array}$ & $\begin{array}{l}-0.135 \\
(0.108)\end{array}$ & $\begin{array}{c}0.075 \\
(0.454)\end{array}$ \\
\hline $\begin{array}{l}\text { Household } \\
\text { Size }\end{array}$ & $\begin{array}{c}0.007 \\
(0.007)\end{array}$ & $\begin{array}{c}-0.035 * * * \\
(0.009)\end{array}$ & $\begin{array}{c}0.001 \\
(0.007)\end{array}$ & $\begin{array}{c}0.016 \\
(0.028)\end{array}$ & $\begin{array}{c}0.031 * * * \\
(0.010)\end{array}$ & $\begin{array}{c}0.016 \\
(0.011)\end{array}$ & $\begin{array}{c}0.007 \\
(0.008)\end{array}$ & $\begin{array}{l}-0.027 \\
(0.039)\end{array}$ \\
\hline
\end{tabular}

See notes for Table 4. 
Table 6: Who Enters Self-Employment from Wage Employment?

\begin{tabular}{|c|c|c|c|c|c|c|c|c|}
\hline & & $\underline{\mathrm{Ma}}$ & ale & & & Fen & nale & \\
\hline & OLF & $\begin{array}{c}\text { Un- } \\
\text { employed }\end{array}$ & $\begin{array}{c}\text { Own } \\
\text { account }\end{array}$ & Employer & OLF & $\begin{array}{c}\text { Un- } \\
\text { employed }\end{array}$ & $\begin{array}{c}\text { Own } \\
\text { account }\end{array}$ & Employer \\
\hline Base Specificat & ion: & & & & & & & \\
\hline Age & $\begin{array}{c}-0.012 * * * \\
(0.002)\end{array}$ & $\begin{array}{c}-0.049 * * * \\
(0.002)\end{array}$ & $\begin{array}{c}0.071 * * * \\
(0.009)\end{array}$ & $\begin{array}{c}0.066^{* * * *} \\
(0.019)\end{array}$ & $\begin{array}{c}-0.173 * * * \\
(0.008)\end{array}$ & $\begin{array}{c}-0.106^{* * *} \\
(0.014)\end{array}$ & $\begin{array}{l}-0.024 \\
(0.016)\end{array}$ & $\begin{array}{l}0.083 * \\
(0.043)\end{array}$ \\
\hline Age Squared & $\begin{array}{c}0.000^{* * *} \\
(0.000)\end{array}$ & $\begin{array}{c}0.000^{* * *} * \\
(0.000)\end{array}$ & $\begin{array}{c}-0.001^{* * *} * \\
(0.000)\end{array}$ & $\begin{array}{c}-0.001^{* *} \\
(0.000)\end{array}$ & $\begin{array}{c}0.002 * * * \\
(0.000)\end{array}$ & $\begin{array}{c}0.001 * * * \\
(0.000)\end{array}$ & $\begin{array}{l}0.000^{*} \\
(0.000)\end{array}$ & $\begin{array}{c}-0.001 * * \\
(0.001)\end{array}$ \\
\hline Primary & $\begin{array}{c}-0.188^{* * *} * \\
(0.061)\end{array}$ & $\begin{array}{l}-0.035 \\
(0.071)\end{array}$ & $\begin{array}{l}-0.082 \\
(0.052)\end{array}$ & $\begin{array}{r}0.296^{* *} \\
(0.143)\end{array}$ & $\begin{array}{c}-0.221^{* * *} \\
(0.054)\end{array}$ & $\begin{array}{c}-0.271^{* * *} \\
(0.094)\end{array}$ & $\begin{array}{c}-0.235^{* *} \\
(0.095)\end{array}$ & $\begin{array}{l}-0.373 \\
(0.287)\end{array}$ \\
\hline Secondary & $\begin{array}{c}-0.381 * * * \\
(0.060)\end{array}$ & $\begin{array}{c}-0.328 * * * \\
(0.067)\end{array}$ & $\begin{array}{c}-0.570 * * * \\
(0.051)\end{array}$ & $\begin{array}{l}-0.118 \\
(0.145)\end{array}$ & $\begin{array}{c}-0.802^{* * *} * \\
(0.053)\end{array}$ & $\begin{array}{c}-0.585^{* * *} * \\
(0.090)\end{array}$ & $\begin{array}{c}-0.714 * * * \\
(0.093)\end{array}$ & $\begin{array}{l}-0.247 \\
(0.261)\end{array}$ \\
\hline Tertiary & $\begin{array}{c}-0.572 * * * \\
(0.067)\end{array}$ & $\begin{array}{c}-0.714 * * * \\
(0.083)\end{array}$ & $\begin{array}{c}-1.007 * * * \\
(0.065)\end{array}$ & $\begin{array}{c}0.459 * * * \\
(0.148)\end{array}$ & $\begin{array}{c}-1.115^{* * *} * \\
(0.056)\end{array}$ & $\begin{array}{c}-1.310 * * * \\
(0.102)\end{array}$ & $\begin{array}{c}-1.015 * * * \\
(0.100)\end{array}$ & $\begin{array}{l}-0.172 \\
(0.263)\end{array}$ \\
\hline Rural area & $\begin{array}{c}0.028 \\
(0.052)\end{array}$ & $\begin{array}{c}0.321 * * * \\
(0.055)\end{array}$ & $\begin{array}{c}0.487 * * * \\
(0.047)\end{array}$ & $\begin{array}{c}0.447 * * * \\
(0.098)\end{array}$ & $\begin{array}{c}0.410 * * * \\
(0.042)\end{array}$ & $\begin{array}{c}0.672 * * * \\
(0.065)\end{array}$ & $\begin{array}{c}0.930 * * * \\
(0.068)\end{array}$ & $\begin{array}{c}0.278 \\
(0.190)\end{array}$ \\
\hline $\begin{array}{l}\text { Change in } \\
\text { unemployment }\end{array}$ & $\begin{array}{c}-1.977 * * * \\
(0.382)\end{array}$ & $\begin{array}{c}4.225^{* * *} * \\
(0.505)\end{array}$ & $\begin{array}{l}-0.165 \\
(0.499)\end{array}$ & $\begin{array}{l}-1.060 \\
(0.833)\end{array}$ & $\begin{array}{c}1.432 * * * \\
(0.290)\end{array}$ & $\begin{array}{c}4.013 * * * \\
(0.441)\end{array}$ & $\begin{array}{l}-0.308 \\
(0.524)\end{array}$ & $\begin{array}{c}5.807 * * * \\
(0.999)\end{array}$ \\
\hline Constant & $\begin{array}{c}-2.493 * * * \\
(0.371)\end{array}$ & $\begin{array}{c}-2.314 * * * \\
(0.515)\end{array}$ & $\begin{array}{c}-2.053 * * * \\
(0.212)\end{array}$ & $\begin{array}{c}-4.089 * * * \\
(0.451)\end{array}$ & $\begin{array}{c}2.320 * * * \\
(0.144)\end{array}$ & $\begin{array}{c}0.295 \\
(0.248)\end{array}$ & $\begin{array}{c}-2.120 * * * \\
(0.301)\end{array}$ & $\begin{array}{c}-5.938^{* * *} * \\
(0.822)\end{array}$ \\
\hline $\begin{array}{l}\text { Country } \\
\text { dummies }\end{array}$ & & $\mathrm{Yc}$ & es & & & $\mathrm{Ye}$ & es & \\
\hline $\begin{array}{l}\text { Number of } \\
\text { observations }\end{array}$ & & 50 & 552 & & & 34,3 & 379 & \\
\hline Adjusted R2 & & 0.0 & 87 & & & 0.0 & 43 & \\
\hline Limited Availab & lity Variab & les : & & & & & & \\
\hline $\begin{array}{l}\text { Household } \\
\text { Head }\end{array}$ & $\begin{array}{c}-0.940 * * * \\
(0.046)\end{array}$ & $\begin{array}{c}-0.836 * * * \\
(0.055)\end{array}$ & $\begin{array}{l}-0.000 \\
(0.050)\end{array}$ & $\begin{array}{c}0.135 \\
(0.105)\end{array}$ & $\begin{array}{c}-0.349 * * * \\
(0.043)\end{array}$ & $\begin{array}{c}-0.236^{* * * *} \\
(0.079)\end{array}$ & $\begin{array}{l}0.119^{*} \\
(0.071)\end{array}$ & $\begin{array}{l}-0.146 \\
(0.177)\end{array}$ \\
\hline Married & $\begin{array}{c}-0.820 * * * \\
(0.069)\end{array}$ & $\begin{array}{c}-0.824 * * * \\
(0.074)\end{array}$ & $\begin{array}{c}0.254 * * * \\
(0.079)\end{array}$ & $\begin{array}{c}0.040 \\
(0.177)\end{array}$ & $\begin{array}{c}0.262^{* * *} \\
(0.064)\end{array}$ & $\begin{array}{l}-0.046 \\
(0.095)\end{array}$ & $\begin{array}{c}0.120 \\
(0.111)\end{array}$ & $\begin{array}{c}0.052 \\
(0.275)\end{array}$ \\
\hline Household Size & $\begin{array}{c}0.036^{* * * *} \\
(0.009)\end{array}$ & $\begin{array}{c}0.065^{* * * *} \\
(0.009)\end{array}$ & $\begin{array}{c}0.003 \\
(0.007)\end{array}$ & $\begin{array}{l}-0.013 \\
(0.018)\end{array}$ & $\begin{array}{c}0.041^{* * *} \\
(0.008)\end{array}$ & $\begin{array}{c}0.036^{* * * *} \\
(0.014)\end{array}$ & $\begin{array}{c}-0.033^{* *} \\
(0.015)\end{array}$ & $\begin{array}{l}-0.045 \\
(0.038)\end{array}$ \\
\hline $\begin{array}{l}\text { Agricultural } \\
\text { Sector }\end{array}$ & $\begin{array}{c}0.183^{* * * *} \\
(0.065)\end{array}$ & $\begin{array}{c}0.302^{* * * *} \\
(0.067)\end{array}$ & $\begin{array}{c}0.266^{* * *} * \\
(0.054)\end{array}$ & $\begin{array}{c}0.447 * * * \\
(0.113)\end{array}$ & $\begin{array}{c}0.176^{* * * *} \\
(0.068)\end{array}$ & $\begin{array}{c}0.877 * * * \\
(0.097) \\
\end{array}$ & $\begin{array}{c}0.314 * * * \\
(0.115)\end{array}$ & $\begin{array}{c}0.911 * * * \\
(0.266) \\
\end{array}$ \\
\hline
\end{tabular}

See notes for Table 4 . 
Table 7: Proportion of Workers Who Are Similar to Employers: among Own-Account Workers and Wage Employees

\begin{tabular}{|c|c|c|c|c|c|c|c|c|c|c|c|}
\hline & Argentina & Brazil & Chile & Indonesia & Mexico & Pakistan & Philippines & $\begin{array}{l}\text { South } \\
\text { Africa } \\
\end{array}$ & Tanzania & Uganda & Average \\
\hline \multicolumn{12}{|l|}{ Men } \\
\hline Own account workers & $62.3 \%$ & $56.8 \%$ & $18.5 \%$ & $57.3 \%$ & $73.5 \%$ & $30.9 \%$ & $5.8 \%$ & $10.2 \%$ & $28.7 \%$ & $13.4 \%$ & $35.7 \%$ \\
\hline Wage Employees & $52.7 \%$ & $47.2 \%$ & $18.9 \%$ & $29.8 \%$ & $54.6 \%$ & $19.1 \%$ & $11.4 \%$ & $18.4 \%$ & $19.8 \%$ & $17.0 \%$ & $28.9 \%$ \\
\hline \multicolumn{12}{|l|}{ Women } \\
\hline Own account workers & $53.3 \%$ & $50.3 \%$ & $21.0 \%$ & $82.9 \%$ & $53.4 \%$ & $0.0 \%$ & $0.7 \%$ & $19.5 \%$ & $16.4 \%$ & $8.5 \%$ & $30.6 \%$ \\
\hline Wage Employees & $43.3 \%$ & $47.2 \%$ & $17.7 \%$ & $45.8 \%$ & $40.5 \%$ & $0.8 \%$ & $1.7 \%$ & $20.0 \%$ & $20.1 \%$ & $20.8 \%$ & $25.8 \%$ \\
\hline
\end{tabular}


Figure 1: Percentage of the Employed Who Change Employment Status While Remaining in the Labor Force, by Gender and Country

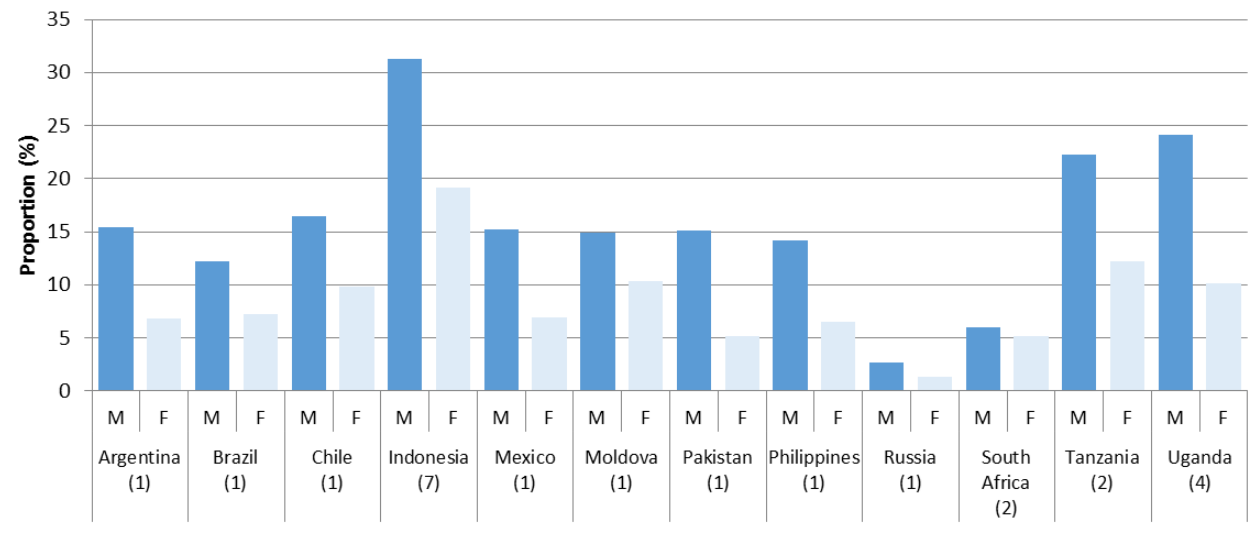

Note: Based on unadjusted transition matrixes. Numbers in parentheses represent time span of surveys. $\mathrm{M}=$ male; $\mathrm{F}=$ female. 
Figure 2: Transition Patterns of Those in the Out-of-Labor-Force Status in the base Period

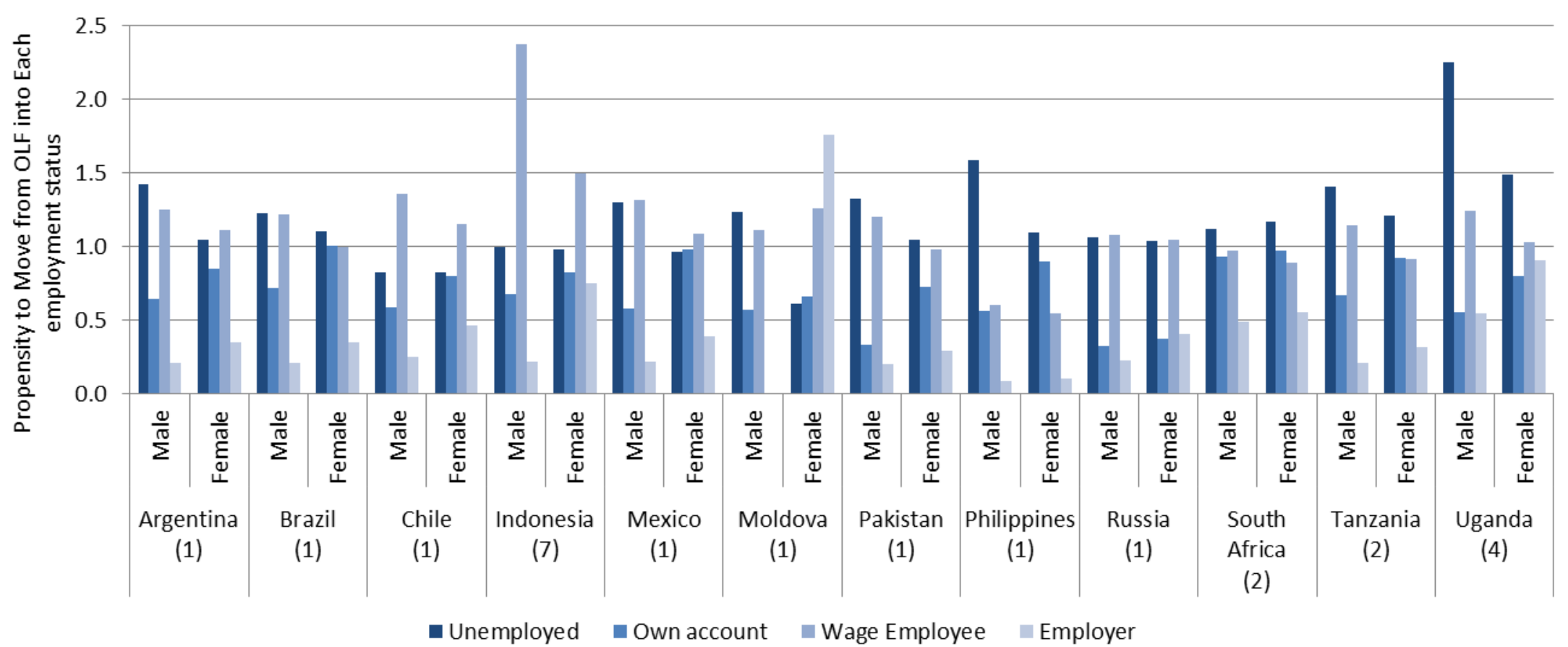

Notes: Based on adjusted transition matrixes, considering the relative size and its change of each employment status, by gender and country; Numbers in parentheses represent time span of surveys. 
Figure 3: Transition Patterns of Own-account Workers in the Base Period

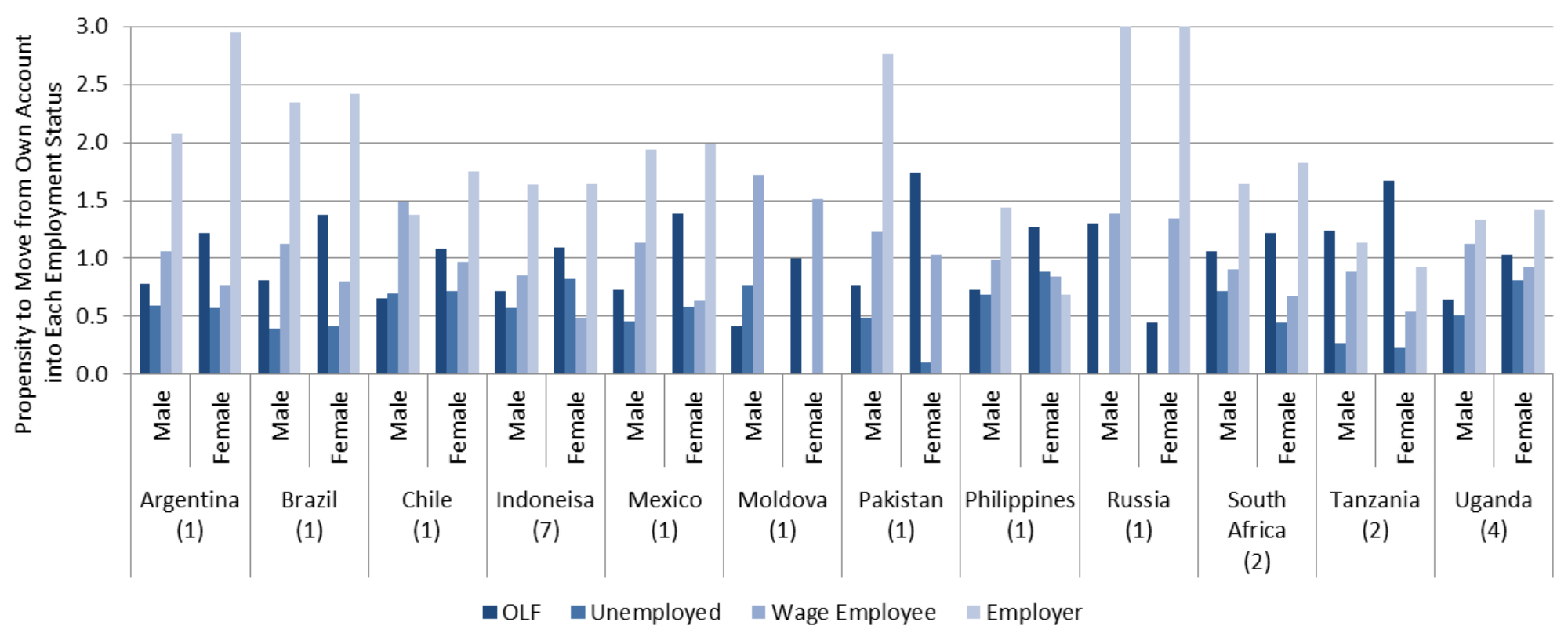

Notes: Based on adjusted transition matrixes, considering the relative size and its change of each employment status, by gender and country; Numbers in parentheses represent time span of surveys. 


\section{Figure 4: Transition Patterns of Employers in the Base Period}

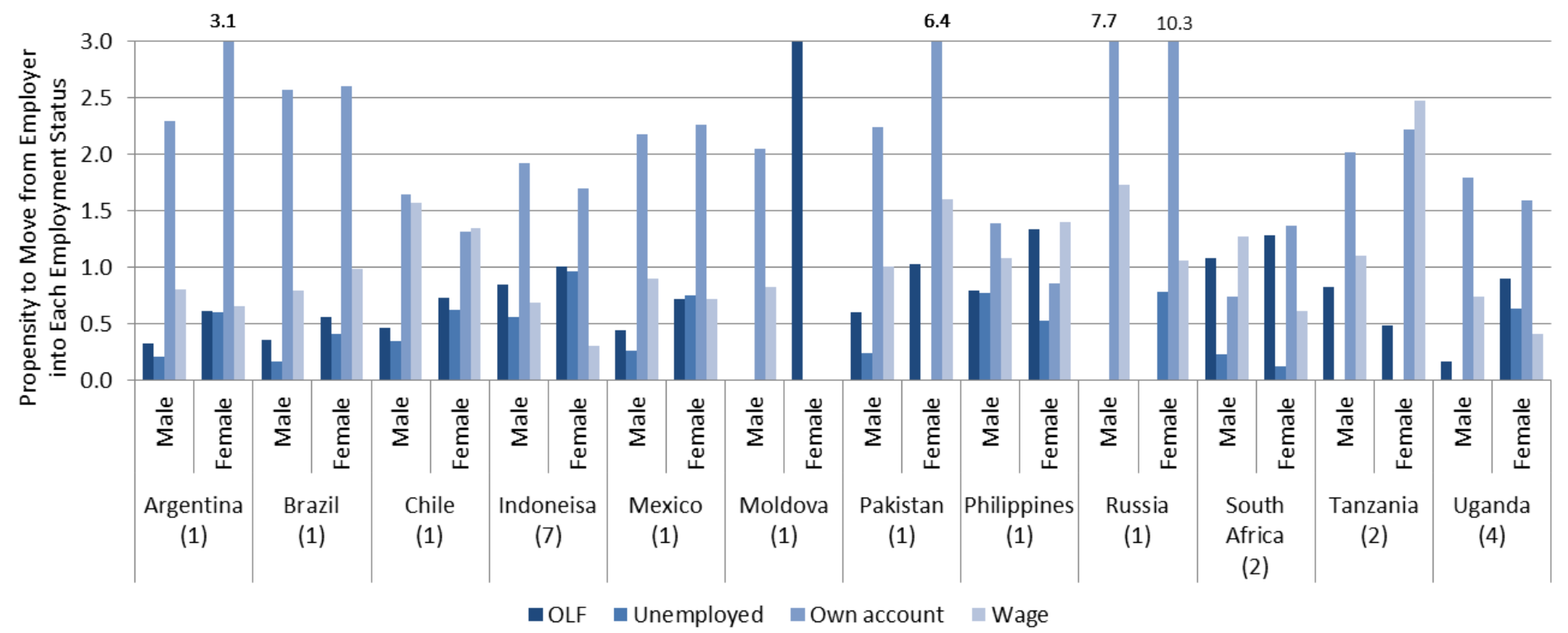

Notes: Based on adjusted transition matrixes, considering the relative size and its change of each employment status, by gender and country; Numbers in parentheses represent time span of surveys; the bars are truncated at 3.0, but in the truncated cases the actual figures are specified. 


\section{Figure 5: Transition Patterns of Wage Employees in the Base Period}

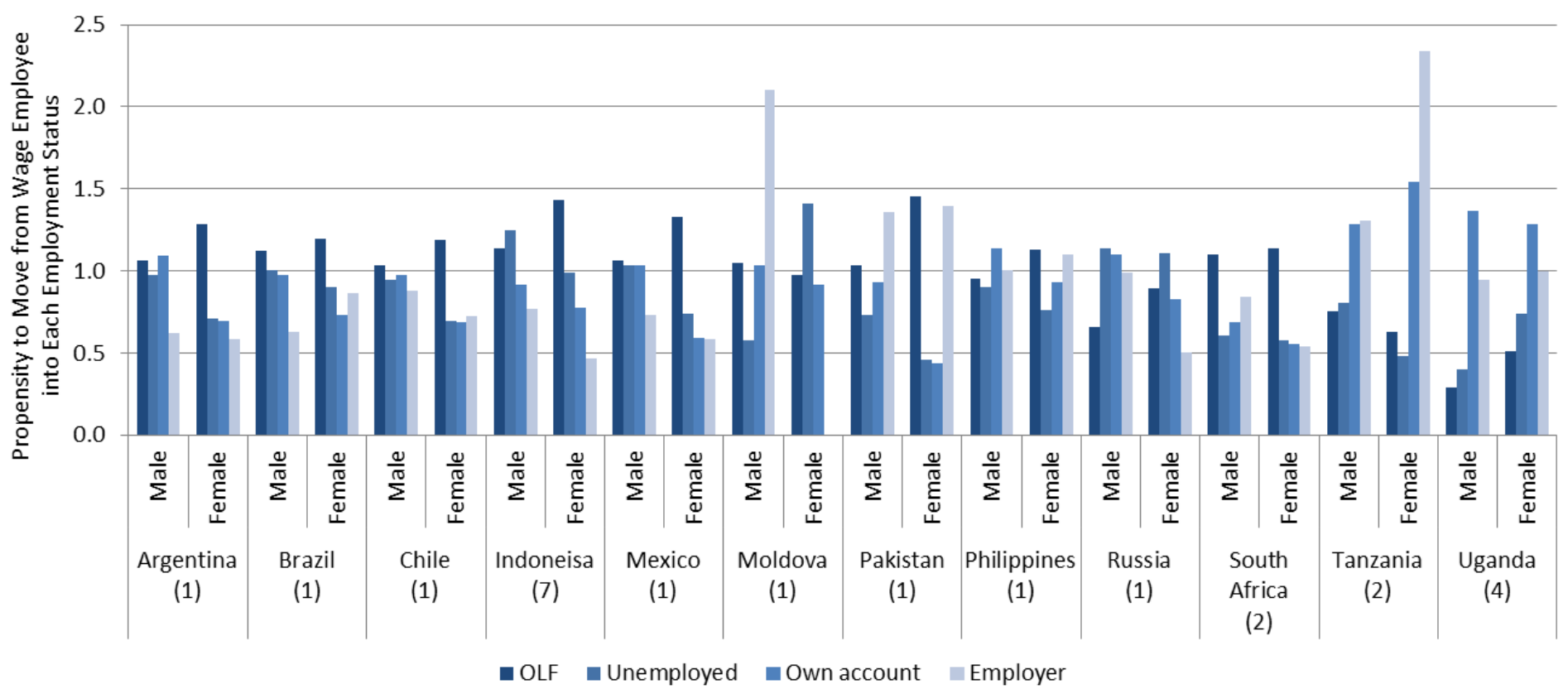

Notes: Based on adjusted transition matrixes, considering the relative size and its change of each employment status, by gender and country; Numbers in parentheses represent time span of surveys. 
Figure 6: Determinants of Transition from Own-Account Workers: to Employer or Wage Employee

\section{A. From Own-account to Employer}
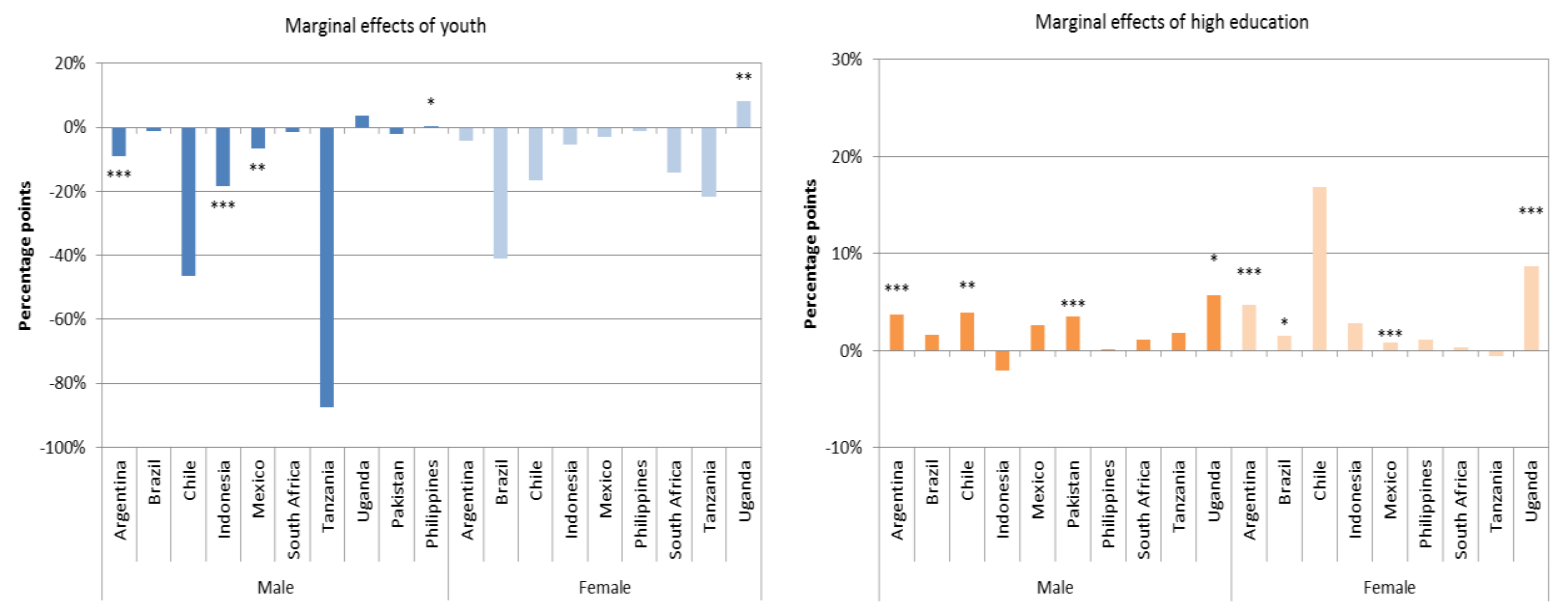

\section{B. From Own-account to Wage Employee}
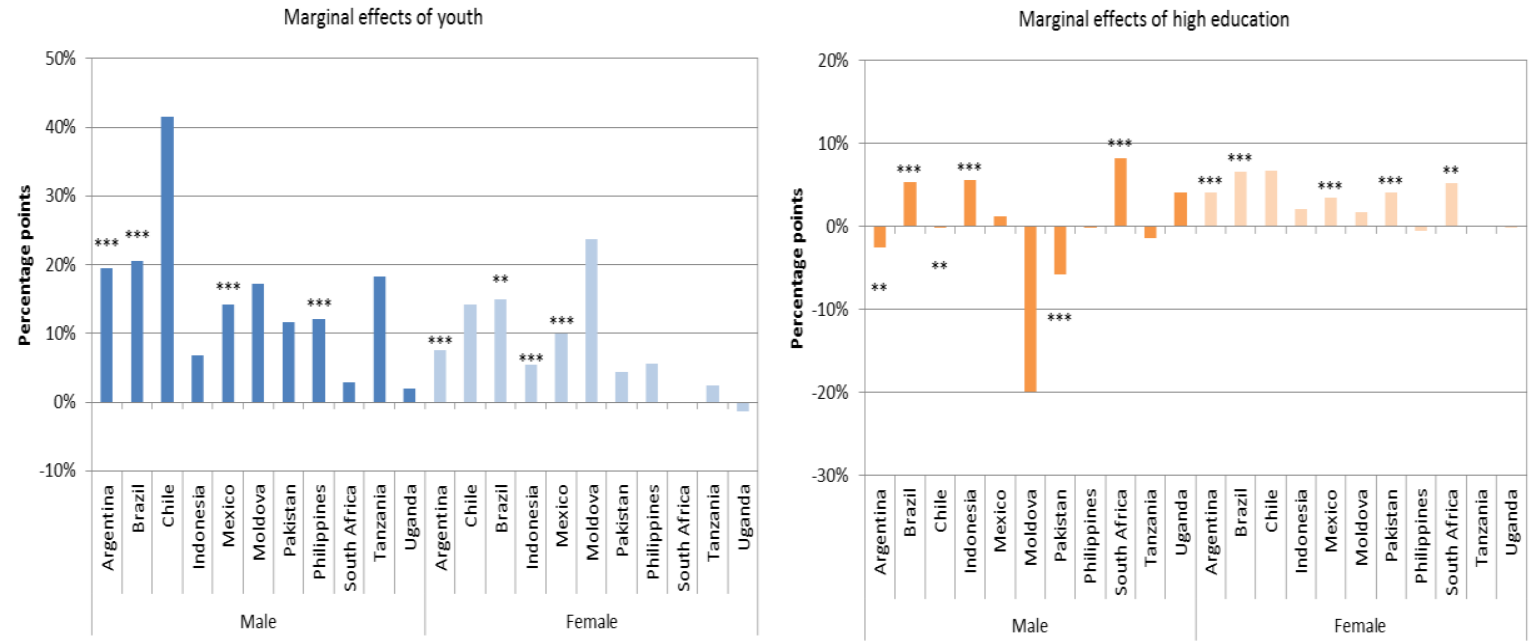

Notes: $* * * \mathrm{p}<0.01, * * \mathrm{p}<0.05, * \mathrm{p}<0.1$; Youth are those aged $15-24$; High education means having a secondary and tertiary education. Estimates are based on multinomial logistic regression for each country, using only those individuals who were own-account workers in the base state. 
Figure 7: Determinants of Transition from the Out-of-Labor-Force Status to Own-account
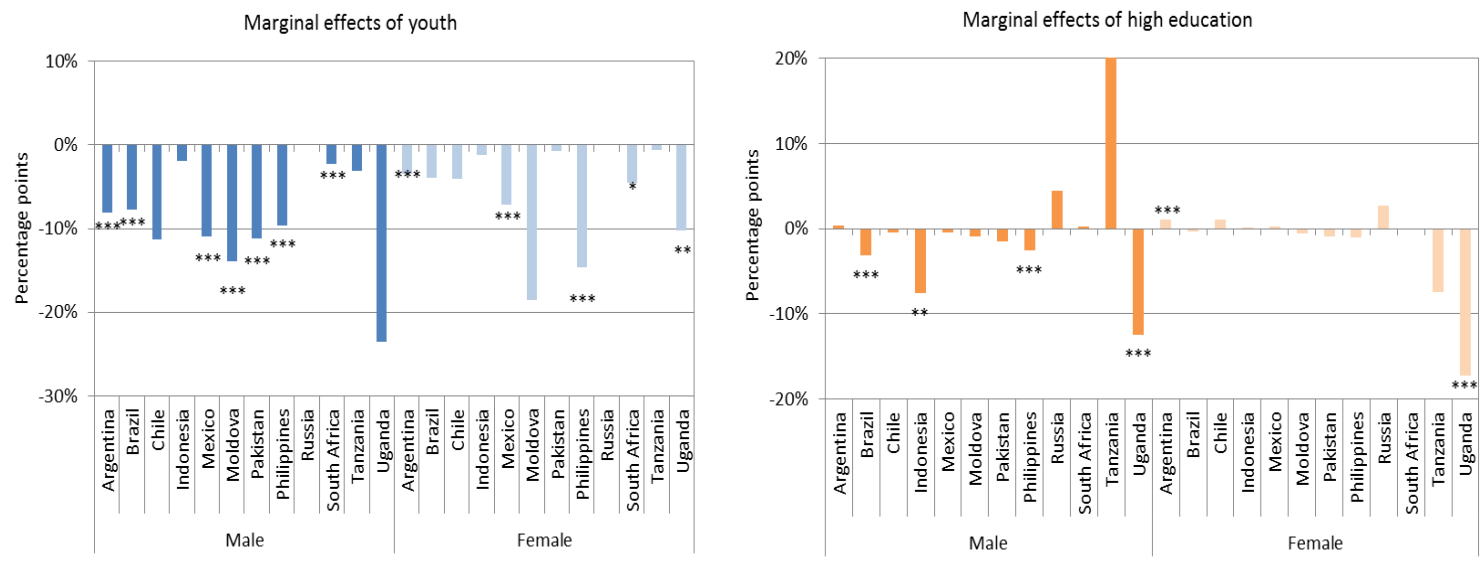

Marginal effects of rural area
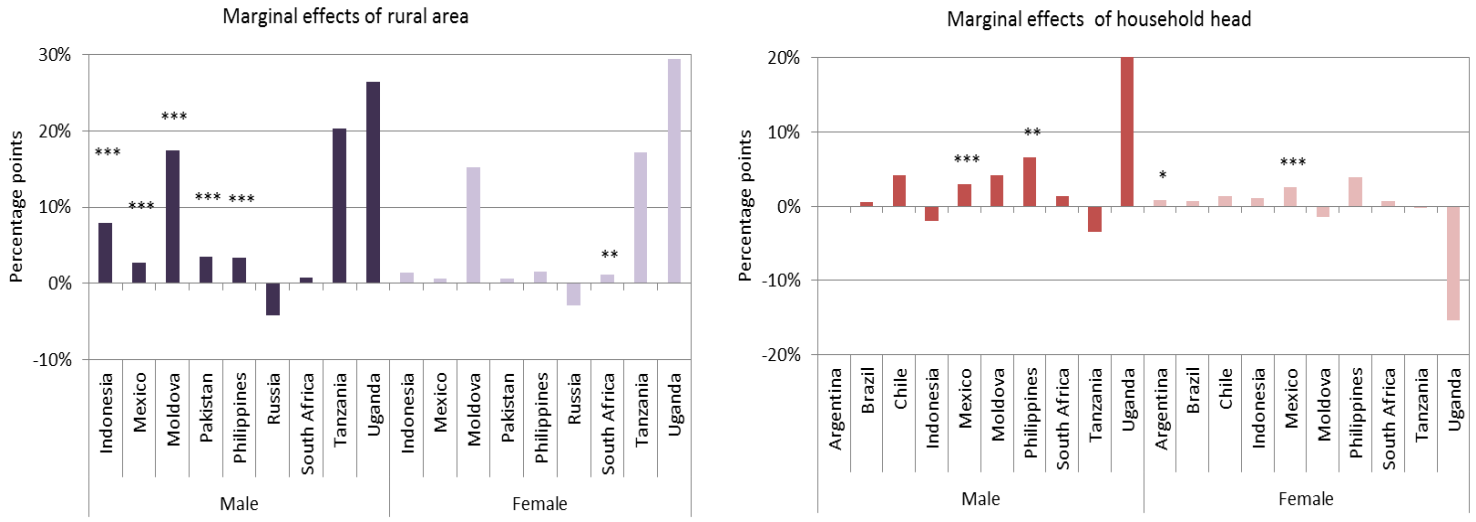

Notes: $* * * \mathrm{p}<0.01, * * \mathrm{p}<0.05, * \mathrm{p}<0.1$; Youth are those aged $15-24$; High education means having a secondary and tertiary education. Estimates are based on multinomial logistic regression for each country, using only those individuals who were OLF in the base state. 


\section{Figure 8: Determinants of Transition from Wage Employment to Own-account}
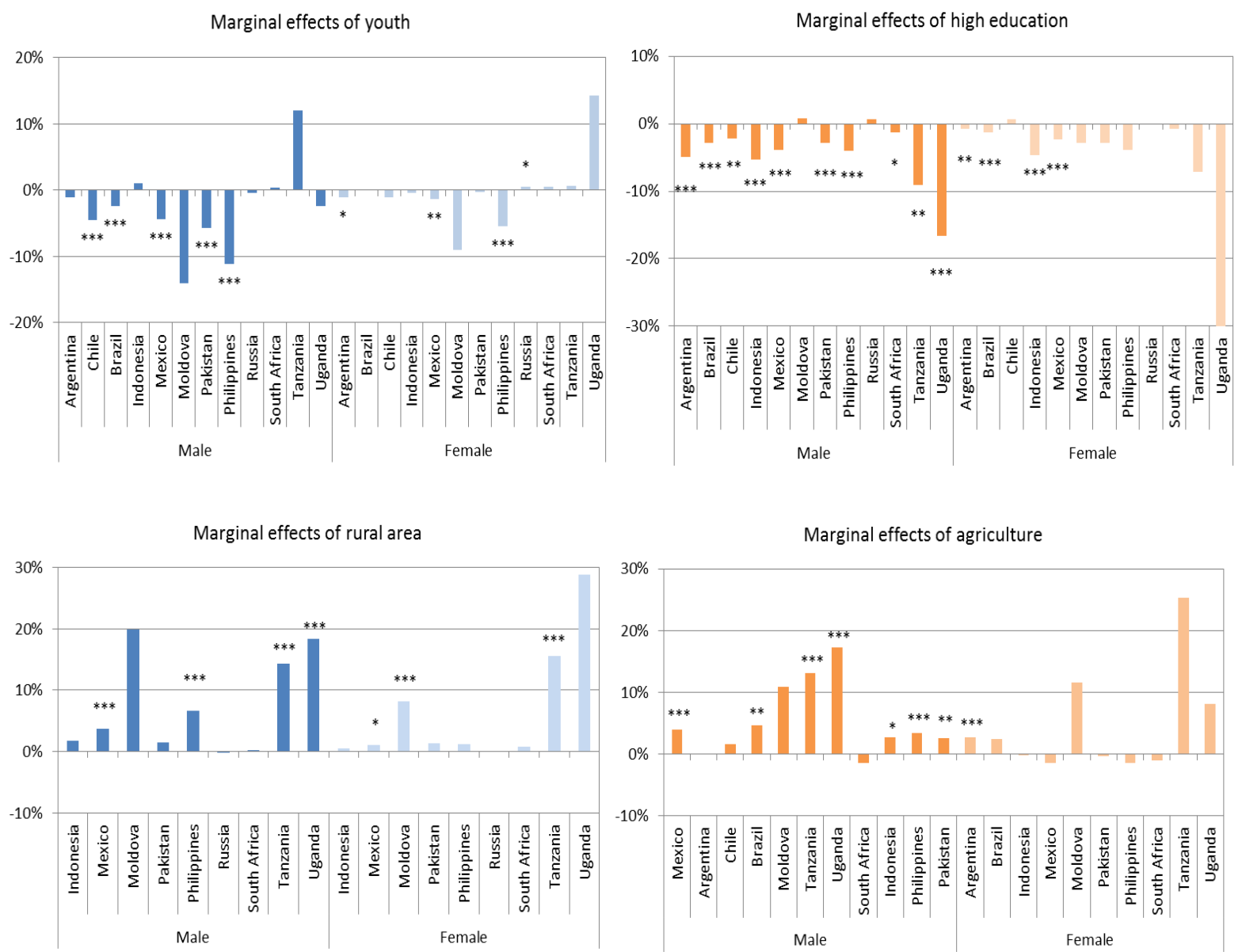

Notes: $* * * \mathrm{p}<0.01, * * \mathrm{p}<0.05, * \mathrm{p}<0.1$; Youth are those aged 15-24; High education means having a secondary and tertiary education. Estimates are based on multinomial logistic regression for each country, using only those individuals who were wage employees in the base state. 
Figure 9: Representation of Wage Employee and Employer Types among Own-Account Workers

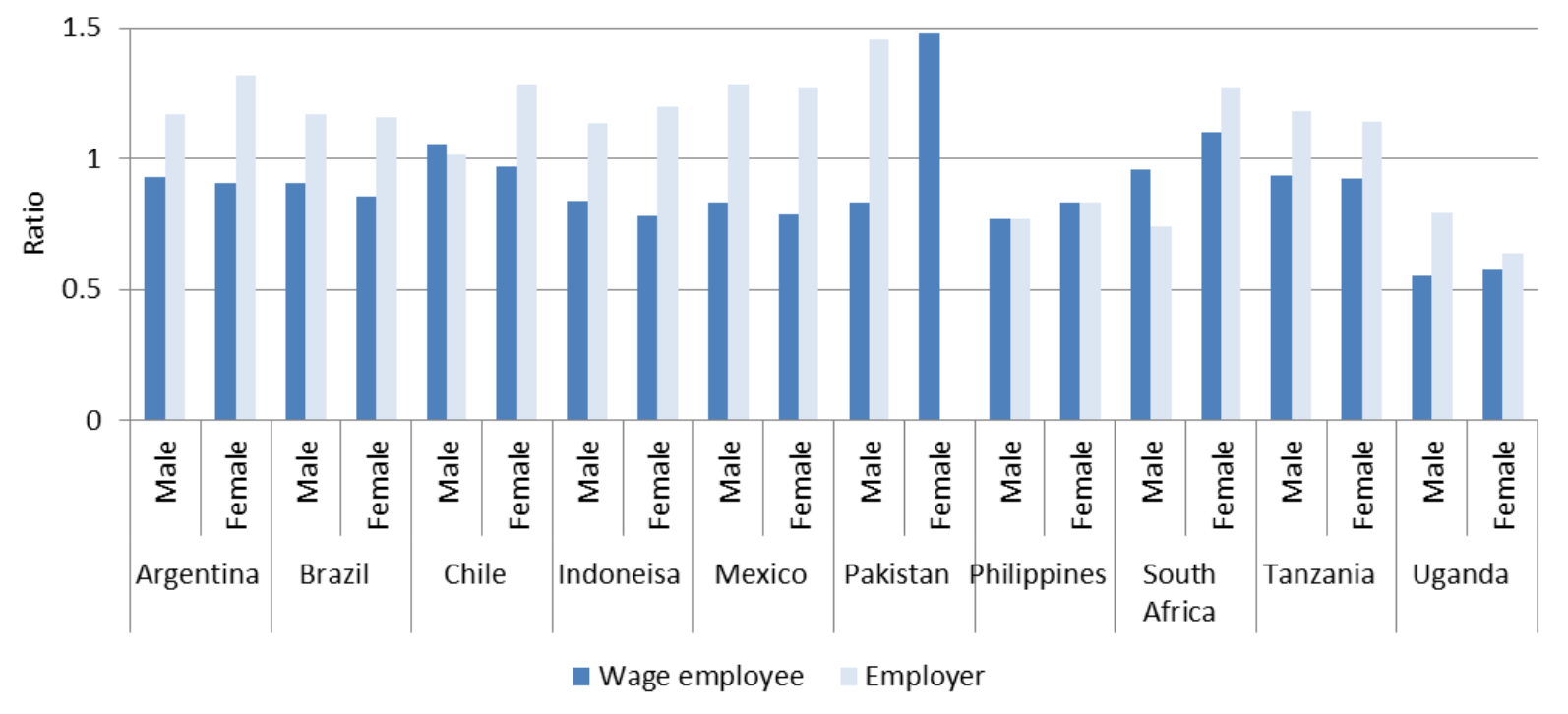

Notes: Based on first method of worker type classification; Bars represent the ratio of the proportion of those classified in each employment type among own account workers relative to the proportion of those classified in that employment type within the whole sample. 
Figure 10: Representation of Own-Account Worker and Wage Employee Types among Employers

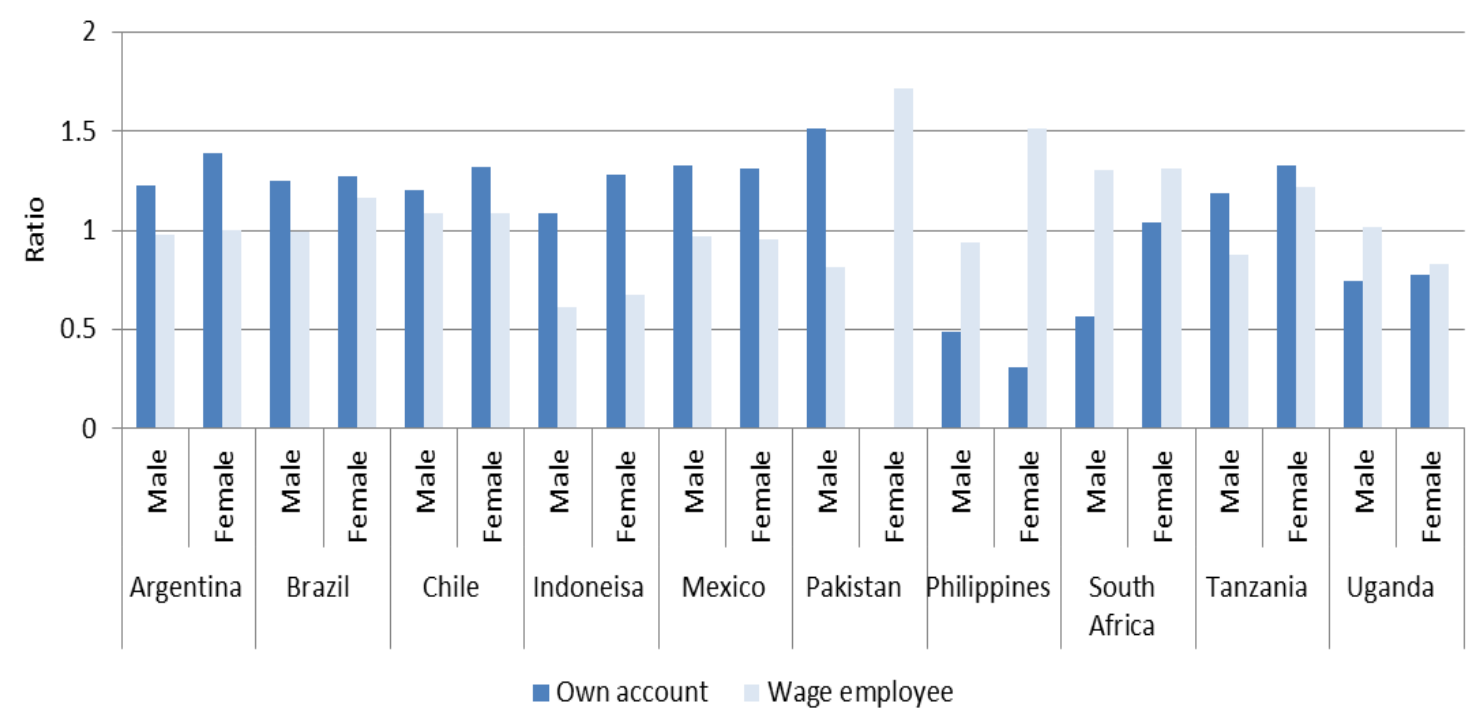

Notes: Based on first method of worker type classification as above; Bars represent the ratio of the proportion of those classified in each employment type among employers relative to the proportion of those classified in that employment type within the whole sample. 


\section{Appendix A. Panel Data Used}

\begin{tabular}{|c|c|c|c|c|c|c|}
\hline Country & Region & Income & Survey name & Type & Frequency & Waves \\
\hline Argentina & LAC & $\begin{array}{l}\text { Upper } \\
\text { Middle }\end{array}$ & $\begin{array}{l}\text { Permanent Household Survey } \\
(\mathrm{EPH})\end{array}$ & $\begin{array}{l}\text { Rotating } \\
\text { panel }\end{array}$ & Quarterly & $\begin{array}{l}\text { Q12005- } \\
\text { Q22012 }\end{array}$ \\
\hline Brazil & LAC & $\begin{array}{l}\text { Upper } \\
\text { Middle }\end{array}$ & $\begin{array}{l}\text { Montlhy Employment Survey } \\
\text { (PME) }\end{array}$ & $\begin{array}{l}\text { Rotating } \\
\text { panel }\end{array}$ & Monthly & $\begin{array}{l}\text { M32002- } \\
\text { M82012 }\end{array}$ \\
\hline Chile & LAC & High & $\begin{array}{l}\text { Quarterly Employment and } \\
\text { Unemployment Survey (EOD) }\end{array}$ & $\begin{array}{l}\text { Rotating } \\
\text { Panel }\end{array}$ & Quarterly & $\begin{array}{l}\text { Q31999- } \\
\text { Q42012 }\end{array}$ \\
\hline Mexico & LAC & $\begin{array}{l}\text { Upper } \\
\text { Middle }\end{array}$ & $\begin{array}{l}\text { National Occupation and } \\
\text { Employment Survey (ENOE) }\end{array}$ & $\begin{array}{l}\text { Rotating } \\
\text { panel }\end{array}$ & Quarterly & $\begin{array}{l}\text { Q12005- } \\
\text { Q32012 }\end{array}$ \\
\hline Moldova & ECA & $\begin{array}{l}\text { Lower } \\
\text { Middle }\end{array}$ & $\begin{array}{l}\text { Household Budget Survey } \\
\text { (HBS) }\end{array}$ & Panel & Annual & 2008-2009 \\
\hline Indonesia & EAP & $\begin{array}{l}\text { Lower } \\
\text { Middle }\end{array}$ & $\begin{array}{l}\text { Indonesia Family life survey } \\
\text { (IFLS) }\end{array}$ & Panel & & 2000,2007 \\
\hline Pakistan & SAR & $\begin{array}{l}\text { Lower } \\
\text { Middle }\end{array}$ & $\begin{array}{l}\text { Pakistan Living Standard } \\
\text { Measurement Survey }\end{array}$ & $\begin{array}{l}\text { Rotating } \\
\text { panel }\end{array}$ & & 2008,2010 \\
\hline Philippines & EAP & $\begin{array}{l}\text { Lower } \\
\text { Middle }\end{array}$ & $\begin{array}{l}\text { Family Income and Expenditure } \\
\text { Survey (FIES) }\end{array}$ & Panel & Annual & $\begin{array}{l}\text { 2006-2007, } \\
\text { 2009-2010. }\end{array}$ \\
\hline Russia & ECA & High & $\begin{array}{l}\text { Russian Longitudinal Monitoring } \\
\text { Survey }\end{array}$ & Panel & Annual & $2002-2003$ \\
\hline South Africa & AFR & $\begin{array}{l}\text { Upper } \\
\text { Middle }\end{array}$ & $\begin{array}{l}\text { National Income Dynamics } \\
\text { Study }\end{array}$ & Panel & & 2008,2010 \\
\hline Tanzania & AFR & Low & National Panel Survey (NPS) & Panel & & 2008,2010 \\
\hline Uganda & AFR & Low & National Panel Survey (NPS) & Panel & & 2005, 2009 \\
\hline
\end{tabular}

Notes: AFR $=$ Sub-Saharan Africa; EAP = East Asia and Pacific $;$ LAC = Latin America and the Caribbean; SAR = South Asia; Urban only for Argentina, Brazil, and Chile 


\section{Appendix B. Additional Figures}

Figure B1: Representation of Wage Employee and Employer Types among Own-Account Workers

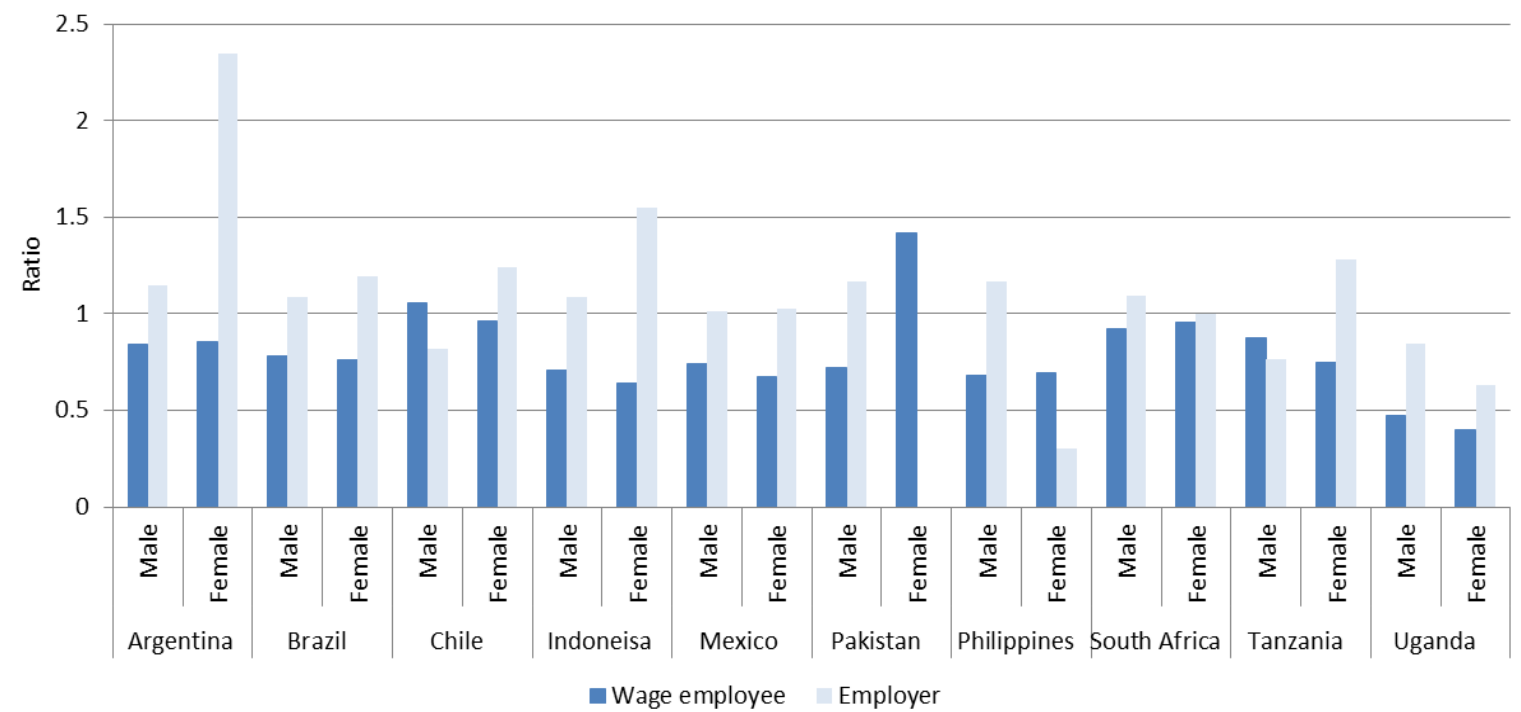

Notes: Replication of Figure 9 using the second method of worker type classification; Bars represent the ratio of the proportion of those classified in each employment type among own account workers relative to the proportion of those classified in that employment type within the whole sample.

Figure B2: Representation of Own-Account Worker and Wage Employee Types among Employers

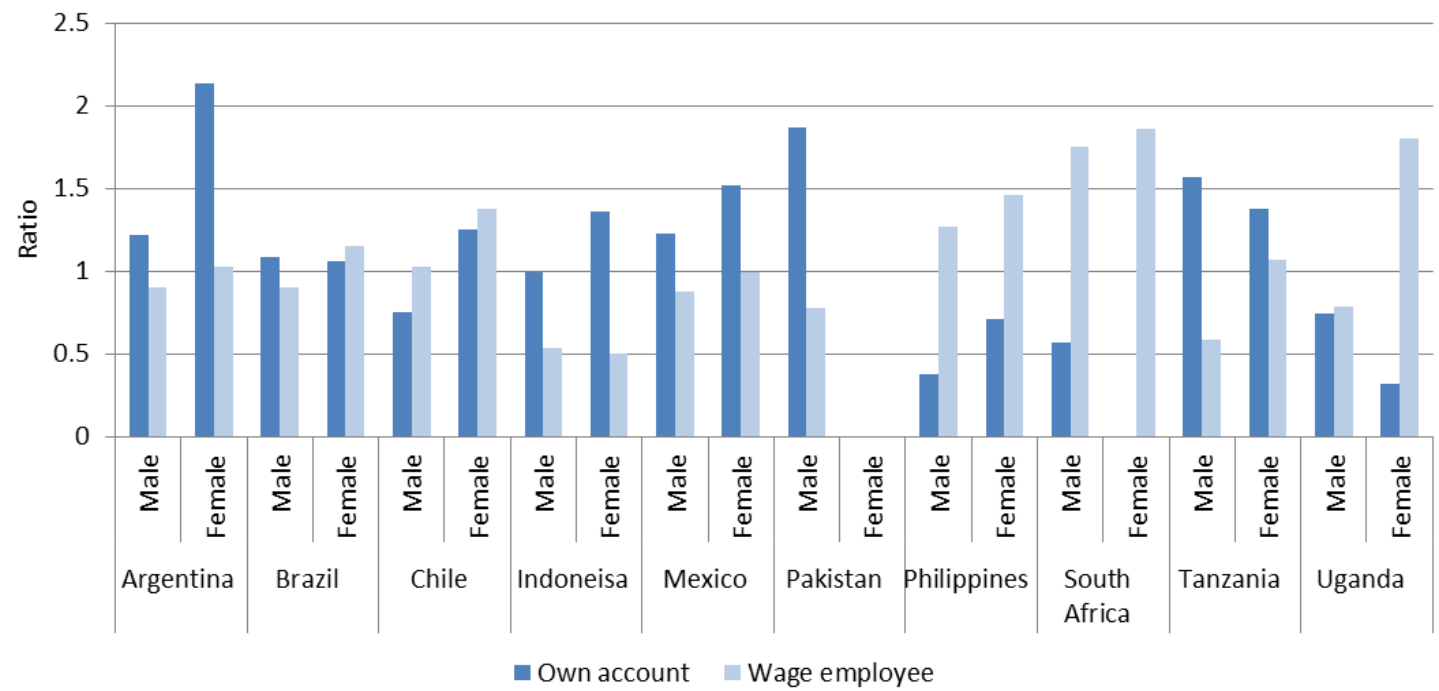

Notes: Replication of Figure 10 using the second method of worker type classification; Bars represent the ratio of the proportion of those classified in each employment type among employers relative to the proportion of those classified in that employment type within the whole sample. 